\title{
Chemical Synthesis of Some Novel 6-Aminouracil- 2-Thiones and Their Glycoside Analogues
}

\author{
A.M. Gaafar ${ }^{a^{*}}$, A.S. Aly ${ }^{\mathrm{a}}$, Khadiga M. Abu-Zied ${ }^{\mathrm{a}}$, Asmaa \\ E. Abdel-Rahman ${ }^{a}$ and M.M. Helmy ${ }^{b}$ \\ ${ }^{a}$ Department of Photochemistry, (Heterocyclic Unit), National \\ Research Centre, Dokki, Giza and ${ }^{b}$ Department of Chemistry, \\ Faculty of Science, Banha University, Banha, Qalubiya, Egypt.
}

\begin{abstract}
6-AMINOURACIL-2-THIONE (1) and its 5-bromo derivative 2 Underwent alkylation yielding their respective S-alkyl products $4_{\mathrm{a}-\mathrm{j}}$. The reaction of compound 1 and aldehydes in the presence of chloroacetic acid afforded the respective thiazolopyrimidinyl acetamides $7_{\mathrm{a}-\mathrm{d}}$. The $\mathrm{C}$-glycosides $8_{\mathrm{a}, \mathrm{b}}$ and $9_{\mathrm{c} \text {-e }}$ were successfully prepared through condensing compound 1 and the appropriate sugar in the presence of chloroacetic acid. The behavior of certain S-alkyl derivative 4 towards amines and hydrazines was also studied. Structure elucidations for the new products were supported by compatible chemical and spectral measurements.
\end{abstract}

Keywords : Aminothiouracil, Glycoside, Nucleoside, NMR and IR .

6-Amino-2-thiouracil (1) and its derivatives are chemically and biologically active compounds. They are used as antithrombotic ${ }^{(1)}$, antimicrobial ${ }^{(2)}$, antiinflammatory ${ }^{(3)}$, antiviral ${ }^{(4)}$, antidotal ${ }^{(2)}$, anticancer agents ${ }^{(2,5)}$ and potent inhibitors of interleukin-8-induced neutrophil chemotaxis ${ }^{(6)}$. Also, they are utilized in other medicinal purposes ${ }^{(7)}$ and as stabilizers in photographic emulsions ${ }^{(8)}$.

Thiouracil derivatives are well-established medications toward cancer diseases. In continuation to our research in drug discovery program, to find new chemical structures acting toward cancer and AIDS, we report here synthesizing new structures based on reacting 6-amino-2-thiouracil with mono- and multifunction groups as well as glucosidation of the new synthesized compounds.

As obvious from all mentioned above, 6-amino-2-thiouracil has a wide range of applications which promote us to use new synthetic routes to gain end products which could be used in many applications.

\section{Results and Discussion}

Treatment of 6-amino-2-thiouracil (or 6-aminouracil-2-thione) (1) with an equimolecular amount of bromine in acetic acid yielded 6-amino-5-bromo-2thiouracil (2) (Scheme 1).

*E-mail: Alaa09@gmail.com 


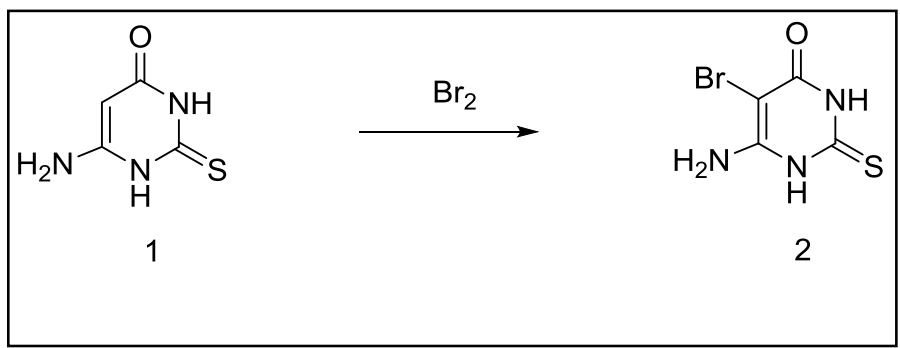

Scheme 1.

Assignment of structure 2 was based on elemental analyses and spectral data. The ${ }^{1} \mathrm{H}-\mathrm{NMR}$ spectrum (DMSO- $d_{6}$ ) shows the lack of the methine proton present at $\delta 4.90 \mathrm{ppm}$ in the spectrum of compound $\mathbf{1}$. Besides, the elemental analysis indicates the presence of bromine atom in the molecule. (See Experimental).

Compound $\mathbf{2}$ is a very important derivative to us, since it simulates 5fluorouracil $\mathbf{3}$ which is a well-known anticancer drug.<smiles>Nc1[nH]c(=O)[nH]c(=O)c1F</smiles>

\section{3}

Reaction of compound $\mathbf{1}$ or $\mathbf{2}$ with the alkylating reagents in ethanolic sodium ethoxide solution produced the 2-alkylthio derivatives 4a-i . (Scheme 2).

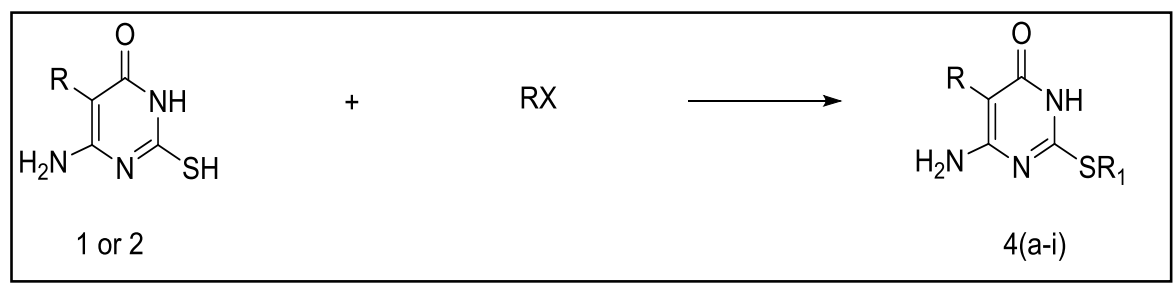

4a; R=H, R1= Me, 4b; R=H, R $=$ Et, 4c; R=H, R $=\mathrm{CH}_{2}$ COOEt, $4 \mathrm{~d} ; \mathrm{R}=\mathrm{H}, \mathrm{R}_{1}=\mathrm{CH}_{2} \mathrm{COph}$, 4e; $\mathrm{R}=\mathrm{H}, \mathrm{R}_{1}=\mathrm{CH}\left(\mathrm{COH}_{3}\right)_{2}, 4 \mathrm{f} ; \mathrm{R}=\mathrm{Br}, \mathrm{R}_{1}=\mathrm{Me}, 4 \mathrm{~g} ; \mathrm{R}=\mathrm{Br}, \mathrm{R}_{1}=\mathrm{Et}, 4 \mathrm{~h} ; \mathrm{R}=\mathrm{Br}, \mathrm{R}_{1}=\mathrm{CH}_{2} \mathrm{COph}$, $4 \mathrm{i} ; \mathrm{R}=\mathrm{Br}, \mathrm{R}_{1}=\mathrm{CH}\left(\mathrm{COH}_{3}\right)_{2}$

\section{Scheme 2 .}

Compound $\mathbf{4 b}$ has been now prepared by a method different from those previously reported ${ }^{(1,9)}$ to give us a better yield and purity. The ${ }^{1} \mathrm{H}-\mathrm{NMR}$ spectrum (DMSO- $d_{6}$ ) of compound $4 \mathbf{e}$ as an example showed signals at $\delta 2.15$ Egypt. J. Chem. 59, No.5 (2016) 
ppm (s, 3H, Me), $\delta 2.55$ ppm (s, 3H, Me), $\delta 5.20 \mathrm{ppm}(\mathrm{s}, 1 \mathrm{H}$, methine proton of the uracil ring), $\delta 6.50$ ppm (br. s, $2 \mathrm{H}, \mathrm{NH}_{2}, \mathrm{D}_{2} \mathrm{O}$ exchangeable), $\delta 7.56 \mathrm{ppm}$ (br. $\mathrm{s}, 1 \mathrm{H}, \mathrm{NH}$, disappeared after $\mathrm{D}_{2} \mathrm{O}$ exchange), $\delta 10.19$ ppm (br. $\mathrm{s}, 1 \mathrm{H}, \mathrm{OH}, \mathrm{D}_{2} \mathrm{O}$ exchangeable). We noticed disappearance of the methine proton in derivative $4 \mathbf{i}$ because of the existence of bromine atom at position 5 .

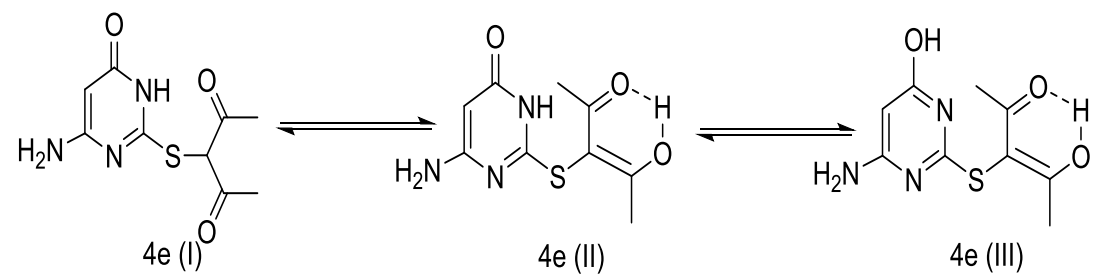

Scheme 3.

Compound $4 \mathbf{e}$ exists mostly in the form $\mathbf{4 e}$ (II). This belief is inferred from the data obtained from DEPT (see Experimental).

The idea of the existence of an equilibrium in the above equation is not appealing for this case since the DEPT experiment duration is long and this experiment ensures so strongly the existence of structure $4 \mathbf{e}$ (II).

Compounds $4 \mathbf{e}$ could exist in the enolic form 4(III), based on the positive result with ferric chloride which develops a deep violet color. That could be understood because the form $\mathbf{4}$ (III) is stabilized by aromaticity and intramolecular hydrogen bonding (Scheme 3).<smiles>Nc1cc(=O)n2c(n1)SCC2=O</smiles>

5

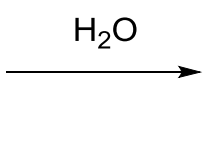

Scheme 4<smiles>Nc1cc(=O)[nH]c(SCC(=O)O)n1</smiles>

6

The S-carboxymethyl derivative $\mathbf{6}$ was previously prepared ${ }^{(8,10)}$ but in a low yield. We report here an alternative method for preparing the same compound in high yield and purity by boiling 2,3-dihydro-5H-7-amino-thiazolo[3,2a]pyrimdine-3,5-dione (5) with water. The spectral and elemental data were identical to those reported in the literature ${ }^{(11,12)}$. 


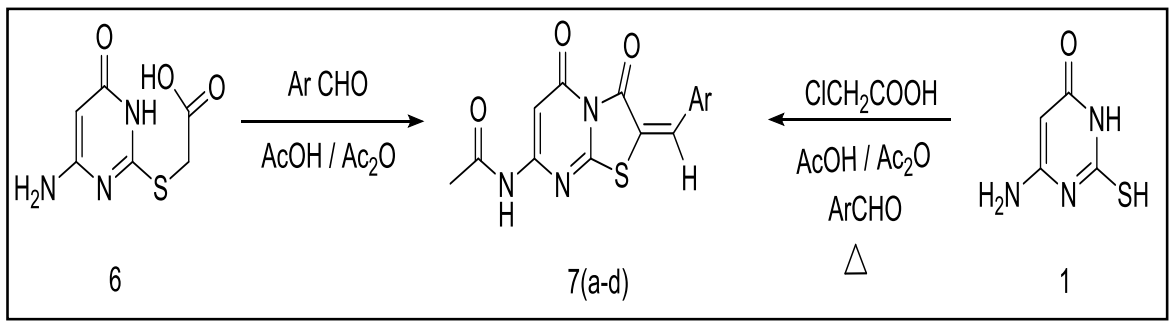

$7 \mathrm{a} ; \mathrm{Ar}=\mathrm{C}_{6} \mathrm{H}_{5}, 7 \mathrm{~b} ; \mathrm{Ar}=\mathrm{C}_{6} \mathrm{H}_{4} \mathrm{OMe}-p, 7 \mathrm{c} ; \mathrm{Ar}=\mathrm{C}_{6} \mathrm{H}_{4} \mathrm{Cl}-p, 7 \mathrm{~d} ; \mathrm{Ar}=\mathrm{C}_{4} \mathrm{H}_{3} \mathrm{~S}$.

Scheme 5 .

Heating under reflux a mixture of $\mathbf{1}$ with chloroacetic acid, an appropriate aromatic aldehyde, anhydrous sodium acetate, glacial acetic acid, and acetic anhydride afforded N-(2-arylidene-6- alkyl-3,5- dioxo-3,5- dihydro- $2 H$-thiazolo [3,2-a] pyrimidin-7-yl) acetamide (7a-d) (see Experimental).

The chemical structure of compound $\mathbf{7 d}$ as an example was inferred through reaction of $\mathbf{6}$ with 2-thiophene aldehyde in glacial acetic acid and acetic anhydride. The IR spectrum of compound $\mathbf{7 d}$ displayed three carbonyl groups at 1710,1696 and $1660 \mathrm{~cm}^{-1}$ (see Experimental). Also, its ${ }^{1} \mathrm{H}$-NMR spectrum (DMSO- $d_{6}$ ) showed signal at $\delta 7.30 \mathrm{ppm}$ (br. s, $1 \mathrm{H}$, disappeared after $\mathrm{D}_{2} \mathrm{O}$ exchange, corresponding to the $\mathrm{NH}$ group) and at $\delta 8.10 \mathrm{ppm}\left(\mathrm{s}, 1 \mathrm{H}, \mathrm{sp}^{2}\right.$ methine proton).

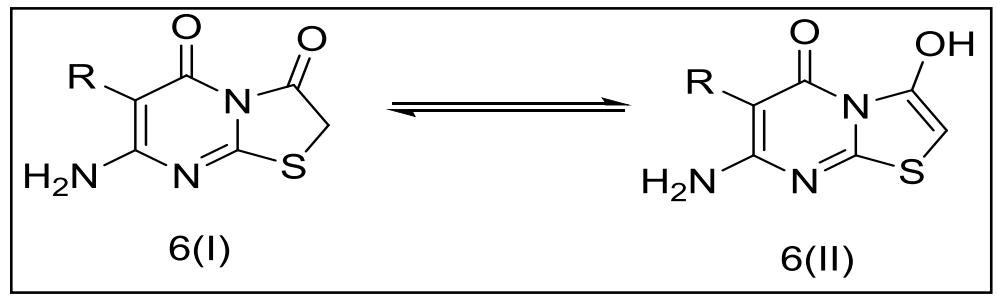

C-Glycosides have been a field of broad interests for their antiviral activities and high selectivity against several viruses like HIV- $1^{(13)}$. These facts encouraged us to synthesize a new C-glycoside from 6-amino-2-thiouracil (1).

Compound $6^{(14)}$ possesses two possible reaction centers to react with aldoses which are the amino group and the methylene group. We report here that the priority for such reaction is the methylene group, which was unexpected. Moreover in a previous work from our research group ${ }^{(15)}$, the reaction was expected to take place on the amino group, due to the tautomerization which makes the reaction on the amino group easier.

So, heating compound $\mathbf{5}$ under reflux in absolute alcohol with aldopentoses namely D-arabinose and D-xylose yielded the corresponding C-glycoside 8(a,b).

Egypt. J. Chem. 59, No.5 (2016) 


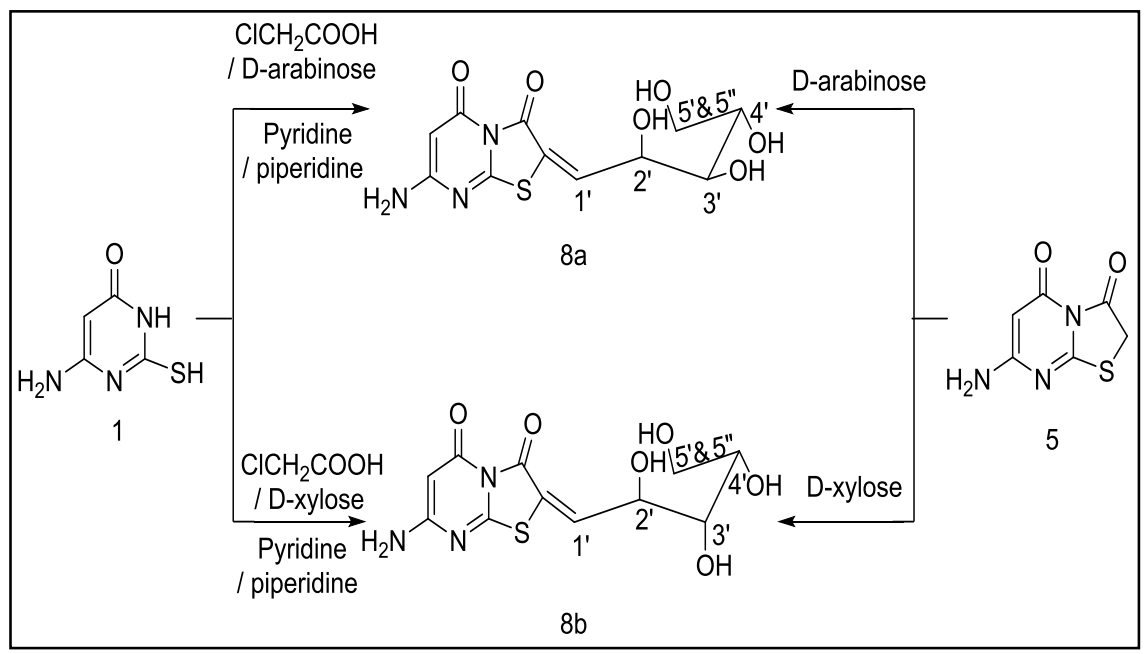

Scheme 6 .

The same reaction could be achieved in one pot-step synthesis starting from 1 and chloroacetic acid in pyridine and a few drops of piperdine ${ }^{(16)}$ (Scheme 6) .

Taking as an example the product with D-arabinose 8a, its IR spectrum displayed absorption bands at $3500 \mathrm{~cm}^{-1}$ (br. corresponding to the $4(\mathrm{OH})$ groups) , $3250 \mathrm{~cm}^{-1}$ for $\mathrm{NH}_{2}$ group , $1685 \mathrm{~cm}^{-1}, 1740 \mathrm{~cm}^{-1}$ for the $(\mathrm{CO})$ of true ketone and tert. amide. The ${ }^{1} \mathrm{H}-\mathrm{NMR}$ spectrum (DMSO- $d_{6}$ ) of compound 8a revealed signals at $\delta 03.70 \mathrm{ppm}\left(\mathrm{m}, 4 \mathrm{H}, \mathrm{OH}-2^{\prime}, \mathrm{OH}-3^{\prime}, \mathrm{OH}-4^{\prime}, \mathrm{OH}-5^{\prime}, \mathrm{D}_{2} \mathrm{O}\right.$ exchangeable $), 4.35$ (m, 1H, H-3 '), 04.45 (m, 1H, H-4'), 4.60 (m, 2H, H-5 , H-5 ') 5.40 (dd,1H, J= $7.50 \mathrm{~Hz}, \mathrm{H}-2^{\prime}$ ), 5.45 (s, $1 \mathrm{H}$, uracil methine proton), 6.50 (br., s., $2 \mathrm{H}, \mathrm{NH}_{2}, \mathrm{D}_{2} \mathrm{O}$ exchangeable), $7.40\left(\mathrm{~d}, 1 \mathrm{H}, 7.50 \mathrm{~Hz}, \mathrm{H}-1^{\prime}\right)$, (for the rest of data see Experimental).

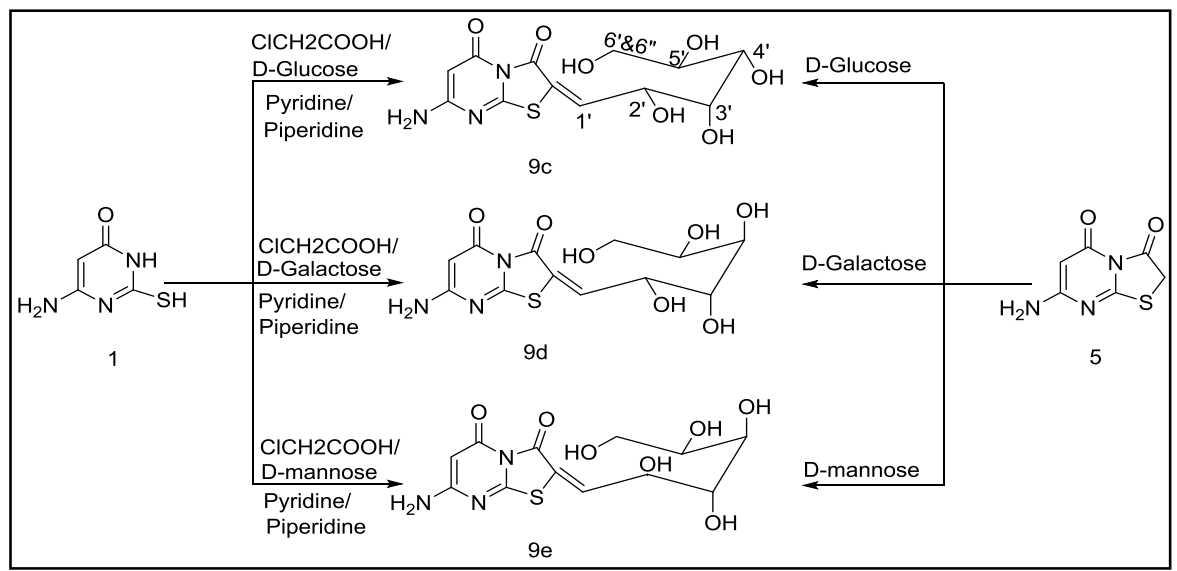

Scheme 7.

Egypt. J. Chem. 59, No.5 (2016) 
Applying the same reaction conditions on aldohexoses namely D-glucose, Dgalactose, and D-manose either by using compound $\mathbf{1}$ or $\mathbf{5}$, afforded the corresponding C-glycosides 9c-e respectively (Scheme 7).

The ${ }^{1} \mathrm{H}-\mathrm{NMR}$ spectrum (DMSO- $d_{6}$ ) of compound 9c as an example, showed signals at $\delta 3.55 \mathrm{ppm}\left(\mathrm{m}, 5 \mathrm{H}, 5 \mathrm{OH}, \mathrm{D}_{2} \mathrm{O}\right.$ exchangeable, OH-2', OH-3', OH-4', OH-5 ', and OH-6 $\left.{ }^{\prime}\right), \delta 3.75$ ppm (m, 1H, H-5'), $\delta 4.30$ ppm (m, 2H, H-6, H-6 ' $)$, $\delta 4.50 \mathrm{ppm}\left(\mathrm{m}, 1 \mathrm{H}, \mathrm{H}-4^{\prime}\right), \delta 4.60 \mathrm{ppm}\left(\mathrm{m}, 1 \mathrm{H}, \mathrm{H}-3^{\prime}\right), \delta 5.00 \mathrm{ppm}(\mathrm{s}, 1 \mathrm{H}$, uracil, methine proton), $\delta 5.50 \mathrm{ppm}\left(\mathrm{m}, 1 \mathrm{H}, \mathrm{H}-2^{\prime}\right), \delta 6.50 \mathrm{ppm}$ (br. s, $2 \mathrm{H}, \mathrm{NH}_{2}$ group, $\mathrm{D}_{2} \mathrm{O}$ exchangeable $), \delta 7.40 \mathrm{ppm}\left(\mathrm{d}, 1 \mathrm{H}, J=7.5 \mathrm{~Hz}, \mathrm{H}-1^{\prime}\right)$.

A simple and conventional method is reported here for cyclization of both compounds $\mathbf{4 d}$ and $\mathbf{4 e}$ via acetylation mechanism.

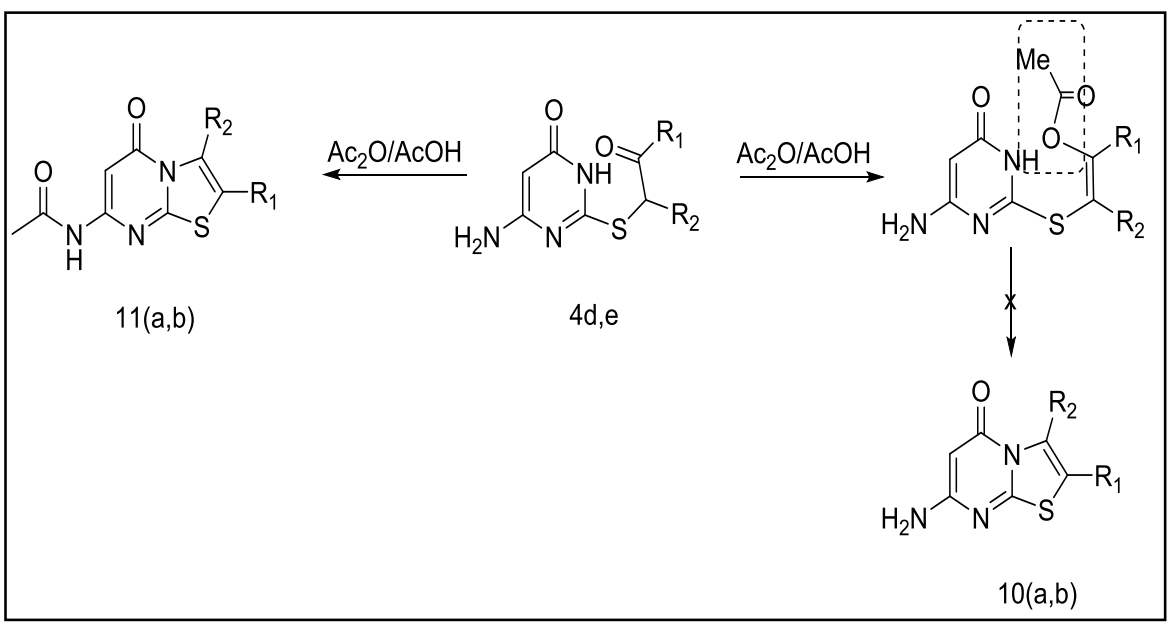

$10 \mathrm{a} ; \mathrm{R}_{1}=\mathrm{COMe}, \mathrm{R}_{2}=\mathrm{CH}_{3}, 11 \mathrm{a} ; \mathrm{R}_{1}=\mathrm{COMe}, \mathrm{R}_{2}=\mathrm{CH}_{3}, 10 \mathrm{~b} ; \mathrm{R}_{1}=\mathrm{H}, \mathrm{R}_{2}=\mathrm{Ph}, 11 \mathrm{~b}$; $\mathrm{R}_{1}=\mathrm{H}, \mathrm{R}_{2}=\mathrm{Ph}$.

Scheme 8.

The amino group in the expected cyclized products $\mathbf{1 0 a}, \mathbf{b}$ was acetylated to give the final products 11a, $\mathbf{b}$.

Structure 11b as an example was confirmed by different spectral data. The IR spectrum of $11 b$ showed absorption band for the NH group at $3150 \mathrm{~cm}^{-1}$. ${ }^{1} \mathrm{H}$ NMR spectrum (DMSO- $d_{6}$ ) of $\mathbf{1 1 b}$, showed signals at $\delta 2.10 \mathrm{ppm}(\mathrm{s}, 3 \mathrm{H}$, methyl of acetyl group), $\delta 6.50 \mathrm{ppm}$ (s, $1 \mathrm{H}$, uracil methine proton), $\delta 7.40-7.60 \mathrm{ppm}(\mathrm{m}$, $5 \mathrm{H}$, aromatic protons), $\delta 8.10 \mathrm{ppm}\left(\mathrm{s}, 1 \mathrm{H}, \mathrm{sp}^{2}\right.$ thiazole proton), $\delta 10.50 \mathrm{ppm}$ (br. s., $1 \mathrm{H}, \mathrm{NH}$ disappeared after $\mathrm{D}_{2} \mathrm{O}$ exchange).

Since acetylation of the free amino group is undesirable from the biological activity view point, another technique was performed to prevent the amino group from acetylation.

Egypt. J. Chem. 59, No.5 (2016) 
Thus, compound 4d (or 4e) was heated at $120-140{ }^{\circ} \mathrm{C}$ with polyphosphoric acid as dehydrating agent, to furnish the corresponding thiazolo[3,2- $a$ ]pyrimidine derivatives $\mathbf{1 0 a}, \mathbf{b}$ with retaining the amino group.

The IR spectrum of compounds $\mathbf{1 0 a}, \mathbf{b}$ showed absorption around $3300 \mathrm{~cm}^{-1}$ $\left(\mathrm{NH}_{2}\right)$. The ${ }^{1} \mathrm{H}-\mathrm{NMR}$ spectrum (DMSO- $\left.d_{6}\right)$ of compound $\mathbf{1 0 b}$, as an example showed signals at $\delta 5.08 \mathrm{ppm}(\mathrm{s}, 1 \mathrm{H}$, uracil methine proton) $\delta 6.50 \mathrm{ppm}$ (br. s, $2 \mathrm{H}$, amino group, disappeared by $\mathrm{D}_{2} \mathrm{O}$ exchange), $\delta 7.37 \mathrm{ppm}\left(\mathrm{s}, 1 \mathrm{H}, \mathrm{sp}^{2}\right.$ thiazole proton), and $\delta 7.40 \mathrm{ppm}(\mathrm{m}, 5 \mathrm{H}$, aromatic protons).

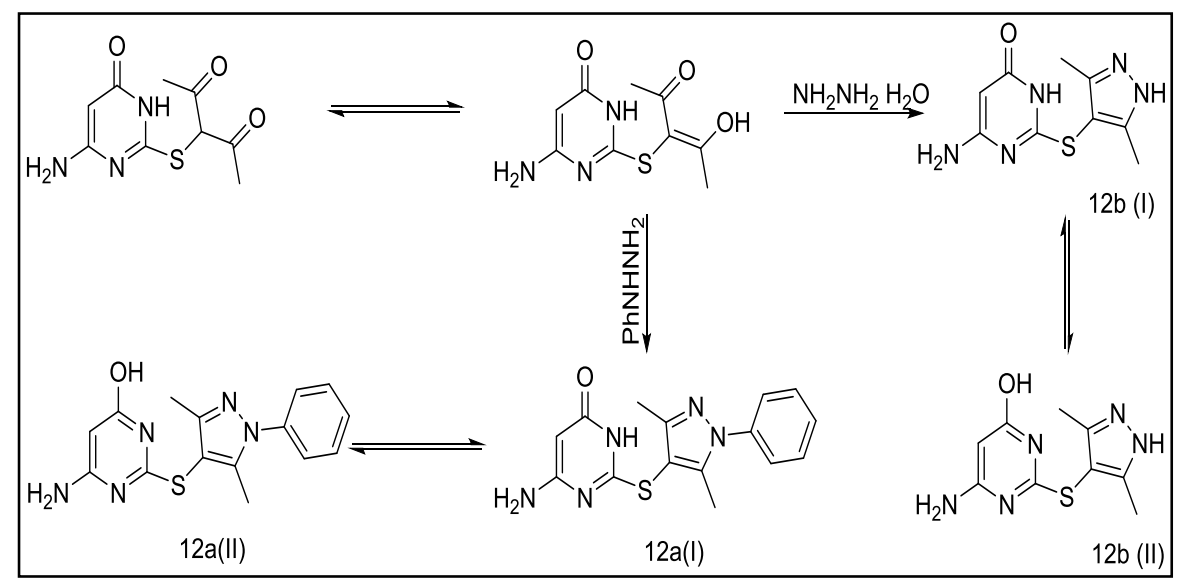

Scheme 9.

The S-alkyl product obtained from reacting compound 1 with 3-chloropentan2,4-dione $\mathbf{4 e}$ was subjected to further investigations. So, heating compound $\mathbf{4 e}$ with phenyl hydrazine or hydrazine hydrate yielded compounds 12a,b (Scheme 8).

Compound 12a(I) can exist in the tautomeric form 12a (II), which is stabilized by the aromaticity of uracil. The structure of the condensed product 12a was based on the correct values of spectral data. The IR spectrum showed ,beside the signals of the amino group and $(\mathrm{C}=\mathrm{O})$ group of 6-amino-2-thiouracil (1), signals in the $(\mathrm{OH})$ and $(\mathrm{NH})$ regions at $3500 \mathrm{~cm}^{-1}$ and $3150 \mathrm{~cm}^{-1}$, which prove the existence of the amide structure 12a(I). The ${ }^{1} \mathrm{H}-\mathrm{NMR}$ spectrum (DMSO- $d_{6}$ ) of compound 12a showed signals at $\delta 02.20 \mathrm{ppm}(\mathrm{s}, 3 \mathrm{H}$, methyl group attached to pyrazole ring), $\delta$ $2.30 \mathrm{ppm}(\mathrm{s}, 3 \mathrm{H}$, other methyl group attached to pyrazole ring), $\delta 5.00 \mathrm{ppm}(\mathrm{s}, 1 \mathrm{H}$, methine proton of the uracil ring), $\delta 6.49$ ppm (br., s., $2 \mathrm{H}$, amino group, disappeared by deuterium oxide exchange), $\delta 7.50 \mathrm{ppm}(\mathrm{m}, 3 \mathrm{H}$, aromatic protons), and $\delta 7.55 \mathrm{ppm}(\mathrm{d}, 2 \mathrm{H}, J=6.8 \mathrm{~Hz}$, aromatic protons).

Heating compound 4a with hydrazine hydrate in ethanol under reflux produced compound $\mathbf{1 3}$ in a good yield (see Experimental).

Egypt. J. Chem. 59, No.5 (2016) 
<smiles>CSc1nc(N)cc(=O)[nH]1</smiles>

$4 a$

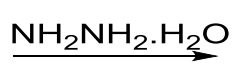<smiles>NNc1nc(N)cc(=O)[nH]1</smiles>

13

Scheme 10.

On other hand, reacting $4 \mathbf{a}$ with aromatic amines by fusion at $140{ }^{\circ} \mathrm{C}$ produced the 2-arylamino derivatives $14 a, b$.<smiles>CSc1nc(N)cc(=O)[nH]1</smiles>

$4 a$<smiles>[X]c1ccc(N)cc1</smiles><smiles>CC(C)(C)C</smiles><smiles>[X]c1ccc(Nc2nc(N)cc(=O)[nH]2)cc1</smiles>

14(a,b)

4a; $\mathrm{X}=\mathrm{H}, 4 \mathrm{~b} ; \mathrm{X}=\mathrm{Cl}$

Scheme 11.

The IR spectrum of $\mathbf{1 4 b}$ proved the existence of a tautomeric structure as it showed absorption bands for $\mathrm{NH}_{2}, \mathrm{NH}, \mathrm{OH}$ groups in the expected places (see Experimental). The ${ }^{1} \mathrm{H}-\mathrm{NMR}$ spectrum (DMSO- $d_{6}$ ) of compound 14a, as an example showed signals at $\delta 5.06 \mathrm{ppm}$ (s, 1H, uracil methine proton), 7.01 (br. s., $4 \mathrm{H}$, disappeared by deuterium oxide exchange, $\mathrm{NH}_{2}$ and $2 \mathrm{NH}$ groups), $\delta 7.50$ ppm (m, $5 \mathrm{H}$, aromatic protons), $\delta 7.55$ ppm (br., s, $1 \mathrm{H}$, disappeared by deuterium oxide exchange, for the enol form of the tautomer 14a) (for the rest of data see Experimental).

\section{Experemnetal}

All reactions were carried out with the exclusion of moisture. All solvents were dried by standard methods. The melting points are uncorrected.

Thin layer chromatography (TLC) was performed by using Merck Alufolien Kieselgel $60 \mathrm{~F}_{254}$ aluminum sheets, and visualization under UV-absorption at $254 \mathrm{~nm}$.

The ${ }^{1} \mathrm{H}-\mathrm{NMR}$ and ${ }^{13} \mathrm{C}-\mathrm{NMR}$ spectra were recorded on Jeol ECA-500 run at $500 \mathrm{MHz}$ for ${ }^{1} \mathrm{H}-\mathrm{NMR}$ and $125 \mathrm{MHz}$ for ${ }^{13} \mathrm{C}-\mathrm{NMR}$, (central Labs at National Research Center) with TMS $\left(\mathrm{SiMe}_{4}\right)$ as an internal standard in $\delta$ units at $295 \mathrm{~K}$, unless otherwise specified. The chemical shifts were expressed in $\delta$-scale (ppm), the coupling constants $\mathrm{J}$ are reported in Hz. The IR spectra were recorded as potassium bromide discs on Jasco FTIR spectrophotometer. Mass spectra were recorded at 70 ev on a GCMS-QP 1000 EX Shimadzu Japan (Gas 
chromatography-Mass spectrometer). Elemental analysis data were performed by the National Research Centre.

\section{6-Amino-5-Bromo-2-Thiouracil (2)}

A solution of bromine $(01.60 \mathrm{gm}, 10 \mathrm{mmole})$ in $20 \mathrm{ml}$ of glacial acetic acid was added drop- wise, with shaking, to a suspension of 1 (01.43 gm, $10 \mathrm{mmole})$ in $40 \mathrm{ml}$ of glacial acetic acid. After the addition was completed and the color of bromine was completely discharged, the reaction mixture was allowed to gentle heating on a water bath for $3 \mathrm{hr}$ with occasional shaking every $5 \mathrm{~min}$, to ensure the ejection of hydrogen bromide gas out of the reaction mixture, then cooled and poured onto ice-water containing a solution of sodium acetate. The colorless precipitate was filtered off, washed thoroughly with water then ethanol, dried and crystallized from dioxane to furnish 2 in good yield (75\%).mp $278{ }^{\circ} \mathrm{C}$ (charring); IR spectrum (KBr, v, cm $\left.{ }^{-1}\right): 3244$ for $\mathrm{NH}_{2}$ group, 3142 for $\mathrm{NH}$ group, 1682 for $\mathrm{CO}$ group; ${ }^{1} \mathrm{H}-\mathrm{NMR}\left(500 \mathrm{MHz}, \mathrm{DMSO}-d_{6}\right) \delta \mathrm{ppm}=3.20(\mathrm{~s}$, $1 \mathrm{H}$, SH disappeared after deuterium oxide exchange), 7.61(br., s, $2 \mathrm{H}, \mathrm{NH}_{2}$, by after deuterium oxide exchange) $12.78 \mathrm{br}$., $\mathrm{s}, 1 \mathrm{H}, \mathrm{OH}$, disappeared by deuterium oxide exchange; Anal.calcd.for $\mathrm{C}_{4} \mathrm{H}_{4} \mathrm{BrN}_{3} \mathrm{OS}(222.06): \mathrm{C}, 21.63 ; \mathrm{H}, 1.82 ; \mathrm{Br}$, 35.98; N, 18.92; S, 14.44\%. Anal. Found; C, 21.36; H, 2.08; Br, 35.78; N, 19.12; $\mathrm{S}, 14.24 \%$. $\mathrm{MS}(\mathrm{m} / \mathrm{z}): 221(41 \%)\left(\mathrm{M}^{+}\right), 223(45 \%)$.

Genral procedures for preparation of 6-amino-2-alkylthio-5-substituted-3,4dihydro-pyrimldln-4-ones (4a-i). (A)

A sodium ethoxide solution (10 mmole) and compound 1 (01.43gm, 10 mmole) or 2 (2.22 gm, $10 \mathrm{mmole})$ were refluxed for $15 \mathrm{~min}$. The reaction mixture was allowed to cool down to room temperature then treated with an equimolecular amount of the proper alkyl halide or $\alpha$-halo ketone. The mixture was heated under reflux for $1 \mathrm{hr}$. The precipitate was separated by pouring the reaction mixture onto $10 \mathrm{ml}$ of ice-water. The solid that formed was filtrated and washed with $10 \mathrm{ml}$ ice-water then dried and crystallized from the proper solvent to give $4 c-i$ in good yield.

(B)

A solution of bromine ( $01.60 \mathrm{gm}, 10 \mathrm{mmole})$ in $20 \mathrm{ml}$ of glacial acetic acid was added dropwise, with shaking, to a suspension of $4 \mathrm{a}$ or $4 \mathrm{~b}$ in $25 \mathrm{ml}$ of glacial acetic. After the addition was completed and the color of bromine was completely discharged, the reaction mixture was allowed to gentle heating on a water bath for $3 \mathrm{hr}$ with occasional shaking every $5 \mathrm{~min}$, to ensure the complete ejection of hydrogen bromide gas, then cooled and poured onto ice-water containing a solution of sodium acetate. The solid that formed was collected with filtration and crystallized from the appropriate solvent to give $4 \mathrm{c}-\mathrm{i}$.

2-Ethyl[6-AMINO-2-THIO-3,4-dihydropyrimldln-4-ONE] Acetate (4c)

Using ethyl bromoacetate. The product was crystallized from isopropanol to furnish $4 \mathrm{c}$ with $70 \%$ yield. $\mathrm{mp} 161^{\circ} \mathrm{C}$; IR spectrum $\left(\mathrm{KBr}, v, \mathrm{~cm}^{-1}\right): 3450 \mathrm{~cm}^{-1}$ (broad) for OH, $3258 \mathrm{~cm}^{-1}$ (broad) for $\mathrm{NH}_{2}, 3150 \mathrm{~cm}^{-1}$ (broad) for NH, $2920 \mathrm{~cm}^{-1}$ 
for $\mathrm{CH}, 1750 \mathrm{~cm}^{-1}$ for $\mathrm{CO}$ (ester), $1680 \mathrm{~cm}^{-1}$ for $\mathrm{CO}$ (amide); ${ }^{1} \mathrm{H}-\mathrm{NMR}(500$ $\left.\mathrm{MHz}, \mathrm{DMSO}-d_{6}\right) \delta \mathrm{ppm}=1.20(\mathrm{t}, 3 \mathrm{H}, J=7.1 \mathrm{~Hz}$, Methyl of the ester group), 3.99 (s, $\left.2 \mathrm{H}, \mathrm{CH}_{2}\right), 4.10\left(\mathrm{q}, 2 \mathrm{H}, \mathrm{J}=7.1 \mathrm{~Hz}, \mathrm{CH}_{2}\right.$ of ester group), 5.01 (s, $1 \mathrm{H}$, methine proton of pyrimidine), 6.46 (br., s, $2 \mathrm{H}, \mathrm{NH}_{2}, \mathrm{D}_{2} \mathrm{O}$ exchangeable), $11.55(\mathrm{br} ., \mathrm{s}, 1 \mathrm{H}$, $\mathrm{OH}, \mathrm{D}_{2} \mathrm{O}$ exchangeable); Anal.calcd.for $\mathrm{C}_{8} \mathrm{H}_{11} \mathrm{~N}_{3} \mathrm{O}_{3} \mathrm{~S}$ (229.3); C, 41.91; H, 04.84; N, 18.33; S,13.99 \%. Anal. Found; C, 41.80; H, 05.07; N, 18.05; S,13.78 \%. $\operatorname{MS}(\mathrm{m} / \mathrm{z}): 229(20 \%)\left(\mathrm{M}^{+}\right)$.

6-Amino-2-(2-OXO-2-phenylethylthio)-3,4-DIHYDRO-PYRIMLDLN-4-ONE (4d)

Using phenacyl bromide. The product was crystallized from ethanol; to produce $4 \mathrm{~d}$ with $85 \%$ yield, $\mathrm{mp} 169^{\circ} \mathrm{C}$; IR spectrum $\left(\mathrm{KBr}, \mathrm{v}, \mathrm{cm}^{-1}\right): 3450 \mathrm{~cm}^{-1}$ (broad) for $\mathrm{OH}$ group, $3268 \mathrm{~cm}^{-1}$ (broad) for $\mathrm{NH}_{2}$ group, $3145 \mathrm{~cm}^{-1}$ (broad) for $\mathrm{NH}$ group, $2925 \mathrm{~cm}^{-1}$ for CH group, $1720 \mathrm{~cm}^{-1}$ for CO (ester), $1688 \mathrm{~cm}^{-1}$ for CO (amide) ${ }^{1} \mathrm{H}-\mathrm{NMR}\left(500 \mathrm{MHz}\right.$, DMSO- $\left.d_{6}\right) \delta \mathrm{ppm}=03.29(\mathrm{~d}, 1 \mathrm{H}, J=11.75 \mathrm{~Hz}$, methine proton of the methylene group(non-diasterotropic proton), 03.66((d, $1 \mathrm{H}$, $J=11.75 \mathrm{~Hz}$, methine proton of the methylene group(non-diasterotropic proton), $05.09(\mathrm{~s}, 1 \mathrm{H}, \mathrm{CH}$, methine proton of uracil), $7.23(\mathrm{~m}, 3 \mathrm{H}$, aromatic protons), $7.56\left(\mathrm{~d}, 2 \mathrm{H}, J=7 \mathrm{~Hz}\right.$, aromatic protons ), 9.14(br., s, $2 \mathrm{H}, \mathrm{NH}_{2}$ group, disappeared after deuterium oxide exchange). Anal.calcd.for $\mathrm{C}_{12} \mathrm{H}_{11} \mathrm{~N}_{3} \mathrm{O}_{2} \mathrm{~S}$ (261.3); C, 55.16; H, 4.24; N, 16.08; S, 12.27\%. Anal. Found; C, 54.16; H, 4.04; N, 16.28; S, $11.90 \%$. MS (m/z): $261(45.0 \%)\left(\mathrm{M}^{+}\right)$.

3-(4-amino-6-oxo-1,6-dihydropyrimidin-2-yl-thio) pentane-2,4-dione (4e)

Using 3-chloropentan-2,4-dione. The product was crystallized from ethanol to produce $4 \mathrm{e}$ with $81 \%$ yield. Mp. $120^{\circ} \mathrm{C}$; IR spectrum $\left(\mathrm{KBr}, \mathrm{v}, \mathrm{cm}^{-1}\right): 3450 \mathrm{~cm}^{-1}$ (broad) for $\mathrm{OH}$ group, $3268 \mathrm{~cm}^{-1}$ (broad) for $\mathrm{NH}_{2}$ group, $3145 \mathrm{~cm}^{-1}$ (broad) for $\mathrm{NH}$ group, $2925 \mathrm{~cm}^{-1}$ for CH group, $1720 \mathrm{~cm}^{-1}$ for $\mathrm{CO}$ (ester), $1688 \mathrm{~cm}^{-1}$ for $\mathrm{CO}$ (amide); ${ }^{1} \mathrm{H}-\mathrm{NMR}\left(500 \mathrm{MHz}, \mathrm{DMSO}-\mathrm{d}_{6}\right) \delta \mathrm{ppm}=2.15\left(\mathrm{~s}, 3 \mathrm{H}, \mathrm{CH}_{3}\right.$, methyl group), $2.55\left(\mathrm{~s}, 3 \mathrm{H}, \mathrm{CH}_{3}\right.$, methyl group), $5.20(\mathrm{~s}, 1 \mathrm{H}, \mathrm{CH}$, methine proton of uracil), 6.50 (br., s, $2 \mathrm{H}, \mathrm{NH}_{2}$ group, $\mathrm{D}_{2} \mathrm{O}$ exchangeable), 7.56(br., s, $1 \mathrm{H}, \mathrm{NH}$ group, $\mathrm{D}_{2} \mathrm{O}$ exchangeable), 10.19 (br., s, $1 \mathrm{H}, \mathrm{OH}$ group, $\mathrm{D}_{2} \mathrm{O}$ exchangeable). DEPT-NMR (125 MHz, DMSO- $\left.d_{6}\right) \delta \mathrm{ppm}=30^{\circ}: 27.1,30.2\left(135^{\circ}\right.$ both up, $90^{\circ}$ :

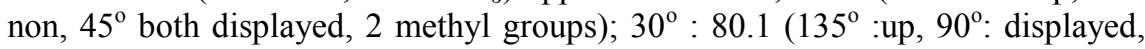
$45^{\circ}$ displayed, Pyrimidine methine sp2 carbon); $30^{\circ}: 98.1$ ( $135^{\circ}$ non, $90^{\circ}$ : non, $45^{\circ}$ non, Quaternary carbon sp2 ethylenic S-carbon atom); $30^{\circ}: 163\left(135^{\circ}\right.$ non, $90^{\circ}$ : non, $45^{\circ}$ non, sp2 Pyrimidine NH2-carbon); $30^{\circ}: 165,167$ (135 $5^{\circ}$ non, $90^{\circ}$ : non, $45^{\circ}$ non, 2 CO groups not involved in hydrogen bond); $30^{\circ}: 202.2\left(135^{\circ}\right.$ non, $90^{\circ}$ : non, $45^{\circ}$ non, $\mathrm{CO}$ group involved in hydrogen bond) Anal.calcd.for $\mathrm{C}_{9} \mathrm{H}_{11} \mathrm{~N}_{3} \mathrm{O}_{3} \mathrm{~S}$ (241.3); C,44.80; H, 4.60; N,17.42; S,13.29\% Anal. Found; C,44.91; $\mathrm{H}, 4.59 ; \mathrm{N}, 17.46 ; \mathrm{S}, 13.26 \%$. MS (m/z): $241(15.0 \%)\left(\mathrm{M}^{+}\right)$.

6-amino-5-bromo-2-meylthio-3,4-dihydropyrimldln-4-one (4f)

Using iodomethane. The product was crystallized from ethanol to produce $4 \mathrm{f}$ with $83 \%$ yield. mp $120^{\circ} \mathrm{C}$; IR spectrum $\left(\mathrm{KBr}, v, \mathrm{~cm}^{-1}\right): 3620 \mathrm{~cm}^{-1}$ (sharp) for OH group, $3502 \mathrm{~cm}^{-1}$ (broad) for $\mathrm{OH}$ intramolecular hydrogen bond, $3290 \mathrm{~cm}^{-1}$ (broad) for $\mathrm{NH}_{2}$ group, $3100 \mathrm{~cm}^{-1}$ (broad) for $\mathrm{NH}$ group, $2950 \mathrm{~cm}^{-1}$ for $\mathrm{CH}$ group, $1666 \mathrm{~cm}^{-1}, 1680 \mathrm{~cm}^{-1}$ for $2(\mathrm{CO})$ groups; ${ }^{1} \mathrm{H}-\mathrm{NMR}\left(500 \mathrm{MHz}\right.$, DMSO- $\left.d_{6}\right)$ Egypt. J. Chem. 59, No.5 (2016) 
$\delta p p m=02.42$ (s, 3H, methyl group), 6.47 (br., s, $2 \mathrm{H}, \mathrm{NH}_{2}, \mathrm{D}_{2} \mathrm{O}$ exchangeable), 11.55(br., s, $1 \mathrm{H}, \mathrm{OH}$ group, $\mathrm{D}_{2} \mathrm{O}$ exchangeable). Anal. calcd. for $\mathrm{C}_{5} \mathrm{H}_{6} \mathrm{BrN}_{3} \mathrm{OS}$ (236.1); C,25.44; H, 2.56; Br, 33.84; N,17.80; S,13.58\% Anal. Found; C,25.44; $\mathrm{H}, 2.56 ; \mathrm{Br}, 33.84 ; \mathrm{N}, 17.80 ; \mathrm{S}, 13.58 \%$. MS (m/z): 235(51 \%) $\left(\mathrm{M}^{+}\right), 237(53 \%)$.

6-amino-5-rromo-2-ethylthio-3,4-dihydropyrimldln-4-one (4g)

Using ethyl bromide. The product was crystallized from isopropanol to produce $4 \mathrm{~g}$ with $89 \%$ yield. $\mathrm{mp} 230^{\circ} \mathrm{C}$; IR spectrum $\left(\mathrm{KBr}, \mathrm{v}, \mathrm{cm}^{-1}\right): 3250 \mathrm{~cm}^{-1}$ (broad) for $\mathrm{NH}_{2}$ group, $3150 \mathrm{~cm}^{-1}$ (broad) for $\mathrm{NH}$ group, $2960 \mathrm{~cm}^{-1}$ for $\mathrm{CH}$ group, $1698 \mathrm{~cm}^{-1}$ for CO (amide). ${ }^{1} \mathrm{H}-\mathrm{NMR}\left(500 \mathrm{MHz}, \mathrm{DMSO}-d_{6}\right) \delta \mathrm{ppm}=$ $1.42(\mathrm{t}, 3 \mathrm{H}, J=7.3 \mathrm{~Hz}$, methyl of the ethyl group), $3.7(\mathrm{q}, 2 \mathrm{H}, J=7.3 \mathrm{~Hz}$, methylene of the ethyl group), 6.46 (br., s, $2 \mathrm{H}, \mathrm{NH}_{2}$ group, $\mathrm{D}_{2} \mathrm{O}$ exchangeable), 11.5 (br., s, OH group (enolic form) of the uracil ring, $\mathrm{D}_{2} \mathrm{O}$ exchangeable). Anal.calcd.for $\mathrm{C}_{6} \mathrm{H}_{8} \mathrm{BrN}_{3} \mathrm{OS}(250.12) ; \mathrm{C}, 28.81 ; \mathrm{H}, 3.22 ; \mathrm{Br}, 31.95 ; \mathrm{N}, 16.80 ; \mathrm{S}$, $12.82 \%$. Anal. Found; C, 28.71; H, 3.1; Br, 31.75; N, 16.90; S, $12.62 \%$. MS(m/z): $249(61 \%)\left(\mathrm{M}^{+}\right), 251(58 \%)$.

6-amino-5-bromo-2-(2-oxo-2-phenylethylthio)-3,4-dihydropyrimldln-4-one (4h)

Using phenacyl bromide. The product was crystallized from dioxane to furnish $4 \mathrm{hr}$ with $80 \%$ yield. $\mathrm{mp} 300^{\circ} \mathrm{C}$; IR spectrum $\left(\mathrm{KBr}, \mathrm{v}, \mathrm{cm}^{-1}\right): 3450 \mathrm{~cm}^{-1}$ (broad) for $\mathrm{OH}, 3260 \mathrm{~cm}^{-1}$ (broad) for $\mathrm{NH}_{2}, 3150 \mathrm{~cm}^{-1}$ (broad) for $\mathrm{NH}, 2950$ $\mathrm{cm}^{-1}$ for $\mathrm{CH} .{ }^{1} \mathrm{H}-\mathrm{NMR}\left(500 \mathrm{MHz}, \mathrm{DMSO}-d_{6}\right) \delta \mathrm{ppm}=3.30(\mathrm{~d}, 1 \mathrm{H}, J=11.75 \mathrm{~Hz}$, methine proton of the methylene group (non diasterotropic protons), 3.61( $\mathrm{d}, 1 \mathrm{H}$, $J=11.75 \mathrm{~Hz}$, methine proton of the methylene group (non diasterotropic protons), 7.01 (br., s, $2 \mathrm{H}, \mathrm{NH}_{2}, \mathrm{D}_{2} \mathrm{O}$ exchangeable), $7.23(\mathrm{~m}, 3 \mathrm{H}$, aromatic protons), 7.56(d, $2 \mathrm{H}, J=7.1 \mathrm{~Hz}$, aromatic protons), 9.14 (br.s, $2 \mathrm{H}, 2 \mathrm{OH}$, disappeared after deuterium oxide exchange); Anal. calcd. for $\mathrm{C}_{12} \mathrm{H}_{10} \mathrm{BrN}_{3} \mathrm{O}_{2} \mathrm{~S}$ (340. 20); C, 42.37; H, 2.96; Br, 23.49; N, 12.35; S, 9.43\%. Anal. Found; C, 42.17; H, 2.90; Br, $23.29 ; \mathrm{N}, 12.15 ; \mathrm{S}, 9.73 \%$. MS (m/z): $339(59 \%), 341(55 \%)\left(\mathrm{M}^{+}\right)$ (4i)

3-(4-amino-5-bromo-6-oxo-1,6-dihydropyrimidin-2-ylthio) pentane-2,4-dione

Using 3-chloropentan-2,4-dione. The product was crystallized from DMF to give $4 \mathrm{i}$ in a $90 \%$ yield. $\mathrm{mp} 180^{\circ} \mathrm{C}$; IR spectrum $\left(\mathrm{KBr}, \mathrm{v}, \mathrm{cm}^{-1}\right): 3720 \mathrm{~cm}^{-1}$ (sharp) for $\mathrm{OH}$ group, $3602 \mathrm{~cm}^{-1}$ (broad) for $\mathrm{OH}$ intramolecular hydrogen bond, 3350 $\mathrm{cm}^{-1}$ (broad) for $\mathrm{NH}_{2}$ group, $3160 \mathrm{~cm}^{-1}$ (broad) for $\mathrm{NH}$ group, $3000 \mathrm{~cm}^{-1}$ for $\mathrm{CH}$ group, $1666 \mathrm{~cm}^{-1}, 1680 \mathrm{~cm}^{-1}$ for 2 (CO) groups. ${ }^{1} \mathrm{H}-\mathrm{NMR}\left(500 \mathrm{MHz}\right.$, DMSO- $\left.d_{6}\right)$ $\delta \mathrm{ppm}=2.15\left(\mathrm{~s}, 3 \mathrm{H}, \mathrm{CH}_{3}\right.$, methyl group ), 2.55( s, $3 \mathrm{H}, \mathrm{CH}_{3}$, methyl group), 7.50 (br., s, $2 \mathrm{H}, \mathrm{NH}_{2}, \mathrm{D}_{2} \mathrm{O}$ exchangeable), 7.65 (br., $\mathrm{s}, 1 \mathrm{H}, \mathrm{NH}, \mathrm{D}_{2} \mathrm{O}$ exchangeable), 10.19 (br.s, $2 \mathrm{H}, 2 \mathrm{OH}, \mathrm{D}_{2} \mathrm{O}$ exchangeable); Anal. calcd. for $\mathrm{C}_{9} \mathrm{H}_{10} \mathrm{BrN}_{3} \mathrm{O}_{3} \mathrm{~S}$ (320); C, 33.76; H, 3.15; Br, 24.96; N, 13.12; S, 10.02\%. Anal. Found; C, 33.96; H, $3.45 ; \mathrm{Br}, 24.70 ; \mathrm{N}, 13.00 ; \mathrm{S}, 10.32 \%$. $\mathrm{MS}(\mathrm{m} / \mathrm{z}): 319(58 \%)\left(\mathrm{M}^{+}\right), 321(61 \%)$.

6-amino-2-carboxymethylthio-3,4-dlhydropyrimldin-4-one (6)

One gram of 5 in $30 \mathrm{ml}$ of water was heated under reflux for $3 \mathrm{hr}$, concentrated and left to cool whereby colorless crystals separated. 
Recrystallization from water gave $90 \%$ yield; which gave positive acidity test. All data matched those reported in literature ${ }^{(11)}$.

General procedures for preparation of $\mathrm{N}$-(2-(4-arylidene)-3,5-dioxo-3,5dihydro-2h-thiazolo[3,2-a]pyrimidine-7-yl)acetamide (A).

A mixture of 1 (01.43 gm, 10 mmole) or 2 (02.22 gm, 10 mmole), (01.04 gm, $10 \mathrm{mmole}$ ) of chloroacetic acid, 10 mmole of the appropriate aldehyde and $2 \mathrm{gm}$ of anhydrous sodium acetate was refluxed in $20 \mathrm{ml}$ of glacial acetic acid and 10 $\mathrm{ml}$ of acetic anhydride for $3 \mathrm{hr}$. The reaction mixture was poured onto ice-water. The deposited precipitate, thus formed, was filtered off, washed thoroughly with water, dried and recrystallized from the appropriate solvent, to produce the pure derivatives $7(\mathrm{a}-\mathrm{d})$

(B)

Compound 5 (2.01 gm, 10 mmole) was refluxed for $3 \mathrm{hr}$. in $20 \mathrm{ml}$ of glacial acetic acid, $10 \mathrm{ml}$ of acetic anhydride, $2 \mathrm{gm}$ of fused sodium acetate and 10 mmole of the appropriate aldehyde to furnish compounds $7(a-d)$.

n-(2-benzylidene-3,5-dioxo-3,5-dihydro-2h-thiazolo[3,2-a]pyrimidine-7-yl) acetamide $(7 a)$

Using benzaldehyde. The product was crystallized from DMF; to give $7 \mathrm{a}$ in an $85 \%$ yield. $\mathrm{mp} 276^{\circ} \mathrm{C}$; IR spectrum $\left(\mathrm{KBr}, v, \mathrm{~cm}^{-1}\right): 3500 \mathrm{~cm}^{-1}$ (sharp) for $\mathrm{OH}$ enolic amide form, $3150 \mathrm{~cm}^{-1}$ for $\mathrm{NH}$ group, $1690 \mathrm{~cm}^{-1}, 1740 \mathrm{~cm}^{-1}$ for 2 (CO) groups. ${ }^{1} \mathrm{H}-\mathrm{NMR}\left(500 \mathrm{MHz}, \mathrm{DMSO}-d_{6}\right) \delta \mathrm{ppm}$ : $2.00\left(\mathrm{~s}, 3 \mathrm{H}, \mathrm{CH}_{3}\right.$, methyl of acetyl group), $7.51(\mathrm{~m}, 3 \mathrm{H}$, aromatic protons $), 7.77(\mathrm{~d}, 2 \mathrm{H}, J=9.01 \mathrm{~Hz}$, aromatic protons), $8.1(\mathrm{~s}, 1 \mathrm{H}$, methine proton of the benzylidene group), 9.10(br., s, $1 \mathrm{H}$, $\mathrm{NH}, \mathrm{D}_{2} \mathrm{O}$ exchangeable). Anal. calcd. for $\mathrm{C}_{15} \mathrm{H}_{11} \mathrm{~N}_{3} \mathrm{O}_{3} \mathrm{~S}$ (313.33) C, 57.50; H, 3.54; N, 13.41; S, 10.23\%. Anal. Found; C, 57.80; H, 3.34; N, 13.11; S, $10.532 \% . \mathrm{MS}(\mathrm{m} / \mathrm{z}): 313(100.0 \%)\left(\mathrm{M}^{+}\right)$.

$N$-(2-(4-methoxybenzylidene)-3,5-dioxo-3,5- dihydro-2h- thiazolo[3,2-a] pyrimidine-7-yl) acetamide (7b)

Using 4-methoxy-benzaldehyde. The product was crystallized from DMF to give $7 \mathrm{~b}$ in an $85 \%$ yield. mp $280^{\circ} \mathrm{C}$; IR spectrum $\left(\mathrm{KBr}, \mathrm{v}, \mathrm{cm}^{-1}\right): 3500 \mathrm{~cm}^{-1}$ (broad) for OH group, $3200 \mathrm{~cm}^{-1}$ (broad) for $\mathrm{NH}, 2900 \mathrm{~cm}^{-1}$ (broad) for $\mathrm{NH}, 2900$ $\mathrm{cm}^{-1} \mathrm{CH}$ group, $1660 \mathrm{~cm}^{-1}, 1698 \mathrm{~cm}^{-1} 1730 \mathrm{~cm}^{-1}$ for 3 (CO) groups. ${ }^{1} \mathrm{H}-\mathrm{NMR}$ $\left(500 \mathrm{MHz}, \mathrm{DMSO}-d_{6}\right) \delta$ ppm: 1.91 ( s, $3 \mathrm{H}, \mathrm{CH}_{3}$, methyl of acetyl group), 3.88( s, $3 \mathrm{H}, \mathrm{CH}_{3}$, methyl of methoxy group), $6.60(\mathrm{~s}, 1 \mathrm{H}$, methine proton of the uracil), $6.88(\mathrm{~d}, 2 \mathrm{H}, J=10 \mathrm{~Hz}, \mathrm{~A}, \mathrm{~B}$ system of the benzene ring ) ,7.20 (br., s, $1 \mathrm{H}, \mathrm{NH}$ group, $\mathrm{D}_{2} \mathrm{O}$ exchangeable), $7.88(\mathrm{~d}, 2 \mathrm{H}, \mathrm{J}=10 \mathrm{~Hz}, \mathrm{~A}, \mathrm{~B}$ system of the benzene ring), $8.1(\mathrm{~s}, 1 \mathrm{H}$, methine proton of the benzylic proton). Anal. calcd. for $\mathrm{C}_{16} \mathrm{H}_{13} \mathrm{~N}_{3} \mathrm{O}_{4} \mathrm{~S}$ (343.36); C, 55.97; H, 3.82; N, 12.24; S, 9.34\%. Anal. Found; C, 55.77; H, 4.02; N, 12.04; S, 9.64\%. $\mathrm{MS}(\mathrm{m} / \mathrm{z}): 343(45 \%)\left(\mathrm{M}^{+}\right)$.

$\mathrm{N}$-(2-(4-chlorobenzylidene)-3,5-dioxo-3,5-dihydro-2h-thiazolo[3,2-a]pyrimidine7-yl)acetamide $(7 c)$

Egypt. J. Chem. 59, No.5 (2016) 
Using 4-chlorobenzaldehyde. The product was crystallized from DMF to give $7 \mathrm{c}$ in an $85 \%$ yield. $\mathrm{mp} 298^{\circ} \mathrm{C}$; IR spectrum ( $\left.\mathrm{KBr}, \mathrm{v}, \mathrm{cm}^{-1}\right): 3500 \mathrm{~cm}^{-1}$ (broad) for $\mathrm{OH}, 3200 \mathrm{~cm}^{-1}$ (broad) for $\mathrm{NH}, 2900 \mathrm{~cm}^{-1}$ (broad) for $\mathrm{NH}, 2900 \mathrm{~cm}^{-1} \mathrm{CH}$ group, $1660 \mathrm{~cm}^{-1}, 1696 \mathrm{~cm}^{-1} 1710 \mathrm{~cm}^{-1}$ for $3(\mathrm{CO})$ groups. ${ }^{1} \mathrm{H}-\mathrm{NMR}(500 \mathrm{MHz}$, DMSO- $\left.d_{6}\right) \delta$ ppm: $2.10\left(\mathrm{~s}, 3 \mathrm{H}, \mathrm{CH}_{3}\right.$, methyl of acetyl group), $7.10(\mathrm{~s}, 1 \mathrm{H}$, methine proton of the uracil ring), $6.88(\mathrm{~d}, 2 \mathrm{H}, J=12 \mathrm{~Hz}, \mathrm{~A}, \mathrm{~B}$ system of the benzene ring), 7.20 (br., s, $1 \mathrm{H}, \mathrm{NH}$ group, $\mathrm{D}_{2} \mathrm{O}$ exchangeable), 07.88 (d, $2 \mathrm{H}, J=$ $12 \mathrm{~Hz}, \mathrm{~A}, \mathrm{~B}$ system of the benzene ring ), $8.1(\mathrm{~s}, 1 \mathrm{H}$, the benzylic proton). Anal. calcd. for $\mathrm{C}_{15} \mathrm{H}_{10} \mathrm{ClN}_{3} \mathrm{O}_{3} \mathrm{~S}(347.78) ; \mathrm{C}, 51.80 ; \mathrm{H}, 2.90 ; \mathrm{Cl}, 10.19 ; \mathrm{N}, 12.08 ; \mathrm{S}$, 9.22\%. Anal. Found; $\mathrm{C}, 52.11 ; \mathrm{H}, 2.60 ; \mathrm{Cl}, 10.25 ; \mathrm{N}, 12.40 ; \mathrm{S}, 9.00 \%$. $\operatorname{MS}(\mathrm{m} / \mathrm{z}): 347(39 \%)\left(\mathrm{M}^{+}\right), 349(42 \%)$.

$N$-(3,5-dioxo-2- (thiophen-2- ylmethylene)-3,5- dihydro-2h-thiazolo[3,2-a] pyrimidine-7-yl)acetamide $(7 d)$

Using 2-thiophene aldehyde. The product was crystallized from DMF to produce $7 \mathrm{~d}$ in a $65 \%$ yield. $\mathrm{mp} 260^{\circ} \mathrm{C}$; IR spectrum $\left(\mathrm{KBr}, \mathrm{v}, \mathrm{cm}^{-1}\right): 3500 \mathrm{~cm}^{-1}$ (broad) for OH, $3200 \mathrm{~cm}^{-1}$ (broad) for NH, $2900 \mathrm{~cm}^{-1} \mathrm{CH}$ group, $1660 \mathrm{~cm}^{-1}$, $1698 \mathrm{~cm}^{-1} 1710 \mathrm{~cm}^{-1}$ for 3 (CO) groups. ${ }^{1} \mathrm{H}-\mathrm{NMR}$ (500 MHz, DMSO-d $d_{6}$ ) $\delta$ ppm: $2.00\left(\mathrm{~s}, 3 \mathrm{H}, \mathrm{CH}_{3}\right.$, methyl of acetyl group), $6.80(\mathrm{~s}, 1 \mathrm{H}$, methine proton of the uracil ring), 7.30 (br., s, $1 \mathrm{H}, \mathrm{NH}$ group, $\mathrm{D}_{2} \mathrm{O}$ exchangeable), $7.67(\mathrm{t}, 1 \mathrm{H}, J=$ $6.65 \mathrm{~Hz}$, thiophene proton, $\left.\mathrm{H}-3^{\prime}\right), 7.60(\mathrm{~d}, 1 \mathrm{H}, J=7.75 \mathrm{~Hz}$, thiophene proton, $\mathrm{H}-$ 4) $) 7.67(\mathrm{~d}, 1 \mathrm{H}, J=7.75 \mathrm{~Hz}$, thiophene proton, $\mathrm{H}-2 \mathrm{c}), 8.1(\mathrm{~s}, 1 \mathrm{H}$, the benzylic proton). Anal. calcd. for $\mathrm{C}_{13} \mathrm{H}_{9} \mathrm{~N}_{3} \mathrm{O}_{3} \mathrm{~S}_{2}(319.36) \mathrm{C}, 48.89 ; \mathrm{H}, 2.84 ; \mathrm{N}, 13.16 ; \mathrm{S}$, $20.08 \% \%$. Anal. Found C, 48.77; H, 3.02; N, 13.35; S, $20.38 \% \%$. MS (m/z): $319(59 \%)\left(\mathrm{M}^{+}\right)$.

General procedure for the preparation of 7-amino-2-aldosyl-2,3-dihyro-5hthiazolo [3,2-a] pyrimidine-3,5-diones $(8 a, b)$ and $(9 c-e)$.

An equimolar amount of $1(01.43 \mathrm{gm}, 10 \mathrm{mmole})$, chloroacetic acid $(10 \mathrm{~m}$ mole, $00.93 \mathrm{gm})$ and the appropriate aldoses $(10 \mathrm{mmole})$ were heated under reflux in $30 \mathrm{ml}$ of pyridine and a catalytic amount of piperidine for $8 \mathrm{hr}$. The mixture was controlled using TLC technique. The mixture was poured onto ice-water and the formed solid was filtered off, and recrystallized from absolute ethanol.

7-amino-2-arabinosyl-2,3-dihyro-5h-thiazolo[3,2-a]pyrimidine-3,5-dione (8a)

Obtained from $\mathrm{D}$-arabinose. The product was produced in a $90 \%$ yield. $\mathrm{mp}$ $270^{\circ} \mathrm{C}$; IR spectrum $\left(\mathrm{KBr}, \mathrm{v}, \mathrm{cm}^{-1}\right), 3500 \mathrm{~cm}^{-1}$ (broad) for OH group, $3250 \mathrm{~cm}^{-1}$ (broad) for $\mathrm{NH}_{2}, 2900 \mathrm{~cm}^{-1}$ for $\mathrm{CH}$ group, $1740 \mathrm{~cm}^{-1}$ and $1685 \mathrm{~cm}^{-1}$ for 2 (CO) groups. ${ }^{1} \mathrm{H}-\mathrm{NMR}\left(500 \mathrm{MHz}\right.$, DMSO- $\left.d_{6}\right) \quad \delta \mathrm{ppm}: 3.70\left(\mathrm{~m}, 4 \mathrm{H}, 4 \mathrm{OH}, \mathrm{D}_{2} \mathrm{O}\right.$ exchangeable), $4.35\left(\mathrm{~m}, 1 \mathrm{H}, \mathrm{CH}, \mathrm{H}-3^{\prime}\right), 4.45\left(\mathrm{~m}, 1 \mathrm{H}, \mathrm{CH}, \mathrm{H}-4{ }^{\prime}\right), 4.60\left(\mathrm{~m}, 2 \mathrm{H}, \mathrm{CH}_{2}\right.$, $\left.\mathrm{H}-5^{\prime}, \mathrm{H}-5^{\prime \prime}\right), 5.40\left(\mathrm{dd}, 1 \mathrm{H}, J=7.5 \mathrm{~Hz}, \mathrm{H}-2^{\prime}\right), 5.45(\mathrm{~s}, 1 \mathrm{H}$, methine proton of uracil ring), 6.50 (br. s, $2 \mathrm{H}, \mathrm{NH}_{2}$ group, $\mathrm{D}_{2} \mathrm{O}$ exchangeable), $7.40(\mathrm{~d}, 1 \mathrm{H}, J=7.5 \mathrm{~Hz}, \mathrm{H}-$ 1' ). Anal.calcd.for $\mathrm{C}_{11} \mathrm{H}_{13} \mathrm{~N}_{3} \mathrm{O}_{6} \mathrm{~S}$ (315.05); Anal. Found; C, 41.90; H, 4.16; N, 13.33 ; S, 10.17\% C, 41.70; H, 4.46; N, 13.03; S, 10.25\%.

7-amino-2-xylosyl-2,3-dihyro-5h-thiazolo[3,2-a] pyrimidine-3,5-dione (8b)

Egypt. J. Chem. 59, No.5 (2016) 
Using D-xylose. The product was obtained in a $90 \%$ yield. $\mathrm{mp} 300{ }^{\circ} \mathrm{C}$ (charred) ; IR spectrum (KBr, v, $\mathrm{cm}^{-1}$ ): $3500 \mathrm{~cm}^{-1}$ (broad) for $\mathrm{OH}$ group, 3250 $\mathrm{cm}^{-1}$ (broad) for $\mathrm{NH}_{2}, 2900 \mathrm{~cm}^{-1}$ for $\mathrm{CH}$ group, $1740 \mathrm{~cm}^{-1}$ and $1685 \mathrm{~cm}^{-1}$ for 2 (CO) groups. ${ }^{1} \mathrm{H}-\mathrm{NMR}\left(500 \mathrm{MHz}, \mathrm{DMSO}-d_{6}\right) \delta \mathrm{ppm}: 03.40\left(\mathrm{~m}, 4 \mathrm{H}, 4 \mathrm{OH}, \mathrm{D}_{2} \mathrm{O}\right.$ exchangeable), 04.25 (q, $\left.1 \mathrm{H}, J=6 \mathrm{~Hz}, \mathrm{CH}, \mathrm{H}-4^{\prime}\right), 4.45\left(\mathrm{~m}, 2 \mathrm{H}, \mathrm{CH}, \mathrm{CH}_{2}, \mathrm{H}-5^{\prime}, \mathrm{H}-\right.$ $\left.5^{\prime \prime}\right), 04.60\left(\mathrm{~d}, 1 \mathrm{H}, \mathrm{CH}, J=5 \mathrm{~Hz}, \mathrm{H}-3^{\prime}\right), 05.80\left(\mathrm{dd}, 1 \mathrm{H}, J=7.5 \mathrm{~Hz}, \mathrm{H}-2{ }^{\prime}\right), 5.95$ ( $\mathrm{s}$, $1 \mathrm{H}$, methine proton of uracil ring), 06.50(br. s, $2 \mathrm{H}, \mathrm{NH}_{2}$ group, $\mathrm{D}_{2} \mathrm{O}$ exchangeable), $7.40\left(\mathrm{~d}, 1 \mathrm{H}, J=7.5 \mathrm{~Hz}, \mathrm{H}-1\right.$ ' ). Anal. calcd. for $\mathrm{C}_{11} \mathrm{H}_{13} \mathrm{~N}_{3} \mathrm{O}_{6} \mathrm{~S}$ (315.05); Anal. Found; C, 41.90; H, 4.16; N, 13.33; S, 10.17\% C, 41.70; H, 4.46; N, $13.03 ; \mathrm{S}, 10.25 \%$.

7-amino-2-glucosyl-2,3-dihyro-5h-thiazolo[3,2-a]pyrimidine-3,5-dione (9c)

Using D-glucose. The product was obtained in a $90 \%$ yield. $\mathrm{mp} 301^{\circ} \mathrm{C}$ (charred); IR spectrum (KBr, v, $\mathrm{cm}^{-1}$ ): $3550 \mathrm{~cm}^{-1}$ (broad) for $\mathrm{OH}$ group,3280 $\mathrm{cm}^{-1}$ (broad) for $\mathrm{NH}_{2}, 2850 \mathrm{~cm}^{-1}$ for $\mathrm{CH}$ group, $1730 \mathrm{~cm}^{-1}$ and $1680 \mathrm{~cm}^{-1}$ for 2 (CO) groups. ${ }^{1} \mathrm{H}-\mathrm{NMR}\left(500 \mathrm{MHz}, \mathrm{DMSO}-d_{6}\right) \delta \mathrm{ppm}: 03.55\left(\mathrm{~m}, 5 \mathrm{H}, 5 \mathrm{OH}, \mathrm{D}_{2} \mathrm{O}\right.$ exchangeable), 3.75 (m, 1H, CH, H-5'), 04.30 (m, 2H, $\left.\mathrm{CH}_{2}, \mathrm{H}-6, \mathrm{H}-6^{\prime \prime}\right)$, $4.50\left(\mathrm{~m}, 1 \mathrm{H}, \mathrm{CH}, \mathrm{H}-4^{\prime}\right), \quad 04.60\left(\mathrm{~m}, 1 \mathrm{H}, \mathrm{CH}, \mathrm{H}-3^{\prime}\right), 5.00(\mathrm{~s}, 1 \mathrm{H}$, methine proton of uracil ring), $05.50\left(\mathrm{~m}, 1 \mathrm{H}, \mathrm{CH}, \mathrm{H}-2^{\prime}\right), 06.50$ (br. s, $2 \mathrm{H}, \mathrm{NH}_{2}$ group, $\mathrm{D}_{2} \mathrm{O}$ exchangeable), $7.40\left(\mathrm{~d}, 1 \mathrm{H}, J=7.5 \mathrm{~Hz}\right.$, methine $\mathrm{H}-1^{\prime}$ '). Anal. calcd. for $\mathrm{C}_{12} \mathrm{H}_{15} \mathrm{~N}_{3} \mathrm{O}_{7} \mathrm{~S}$ (345.33); C, 41.74; H, 4.38; N, 12.17; S, $9.29 \%$. Anal. Found; $\mathrm{C}$, 41.56; H, 4.50; N, 12.37; S, $9.00 \%$.

7-amino-2-galactosyl-2,3-dihyro-5h-thiazolo[3,2-a]pyrimidine-3,5-dione (9d)

Using D-galactose. The product was obtained in a $90 \%$ yield. mp $311^{\circ} \mathrm{C}$ (charred); IR spectrum (KBr, v, $\mathrm{cm}^{-1}$ ): $3550 \mathrm{~cm}^{-1}$ (broad) for $\mathrm{OH}$ group, 3280 $\mathrm{cm}^{-1}$ (broad) for $\mathrm{NH}_{2}, 2850 \mathrm{~cm}^{-1}$ for $\mathrm{CH}$ group, $1730 \mathrm{~cm}^{-1}$ and $1680 \mathrm{~cm}^{-1}$ for 2 (CO) groups. ${ }^{1} \mathrm{H}-\mathrm{NMR}\left(500 \mathrm{MHz}, \mathrm{DMSO}-d_{6}\right) \delta \mathrm{ppm}$ : 03.75(m, 5H, $5 \mathrm{OH}, \mathrm{D}_{2} \mathrm{O}$ exchangeable), 4.20 (m, 2H, CH, ,H-6 ',H-6"), 4.50 (m, 3H, 3CH, H-3' , H-4' , $\left.\mathrm{H}-5^{\prime}\right), 5.00(\mathrm{~s}, 1 \mathrm{H}$, methine proton of uracil ring), $5.20(\mathrm{~d}, 1 \mathrm{H}, J=7.5 \mathrm{~Hz}, \mathrm{CH}$, $\mathrm{H}-2^{\prime}$ ), 06.40 (br. $\mathrm{s}, 2 \mathrm{H}, \mathrm{NH}_{2}$ group, $\mathrm{D}_{2} \mathrm{O}$ exchangeable), $7.40(\mathrm{~d}, 1 \mathrm{H}, J=7.5 \mathrm{~Hz}$, methine $\mathrm{H}-1$ ' ). Anal. calcd. for $\mathrm{C}_{12} \mathrm{H}_{15} \mathrm{~N}_{3} \mathrm{O}_{7} \mathrm{~S}$ (345.33); C, 41.74; H, 4.38; N, 12.17; S, 9.29 \%. Anal. Found; C, 41.56; H, 4.50; N, 12.37; S, $9.00 \%$.

7-amino-2-mannosyl-2,3-dihyro-5h-thiazolo[3,2-a]pyrimidine-3,5-dione (9e)

Using D-mannose. The product was obtained in a $90 \%$ yield. $\mathrm{mp} 305^{\circ} \mathrm{C}$ (charred); IR spectrum (KBr, v, cm $\mathrm{cm}^{-1}$ ): $3550 \mathrm{~cm}^{-1}$ (broad) for $\mathrm{OH}$ group, $3280 \mathrm{~cm}^{-1}$ (broad) for $\mathrm{NH}_{2}, 2850 \mathrm{~cm}^{-1}$ for $\mathrm{CH}$ group, $1730 \mathrm{~cm}^{-1}$ and $1680 \mathrm{~cm}^{-1}$ for 2 (CO) groups. ${ }^{1} \mathrm{H}-\mathrm{NMR}\left(500 \mathrm{MHz}, \mathrm{DMSO}-d_{6}\right)$ sppm: $03.60\left(\mathrm{~m}, 5 \mathrm{H}, 5 \mathrm{OH}, \mathrm{D}_{2} \mathrm{O}\right.$ exchangeable), 4.25 (m, 1H, CH ,H-3'), 4.35 (m, 2H, $\mathrm{CH}_{2}$,H-6 ,H-6"), 4.50 (m, $2 \mathrm{H}, 2 \mathrm{CH}, \mathrm{H}-3$ ' , H-4' ), 5.00 ( $\mathrm{s}, 1 \mathrm{H}$, methine proton of uracil ring), 5.20 (dd, $1 \mathrm{H}$, $J=7.5 \mathrm{~Hz}, \mathrm{CH}, \mathrm{H}-2^{`}$ ) , 6.55(br. s, $2 \mathrm{H}, \mathrm{NH}_{2}$ group, $\mathrm{D}_{2} \mathrm{O}$ exchangeable), 6.65 (d, 1H, $J=7.5 \mathrm{~Hz}$, methine $\mathrm{H}-1$ ' ). Anal. calcd. for $\mathrm{C}_{12} \mathrm{H}_{15} \mathrm{~N}_{3} \mathrm{OS}$ (345.33); C, 41.74; H, 4.38; N, 12.17; S, 9.29 \%. Anal. Found; C, 41.56; H, 4.50; N, 12.37; S, $9.00 \%$. 
General procedure for the preparation of 2-alkyl-7-amino-3-substituted-5hthiazolo[3,2-a]pyrimidin -5-one (10a-b). (A)

A mixture of $2 \mathrm{gm}$ of $4 \mathrm{~d}$ ( or $4 \mathrm{e}$ ) in $10 \mathrm{gm}$ of polyphosphoric acid (prepared by dissolving $5 \mathrm{gm}$ of phosphorus pentoxide in $5 \mathrm{ml}$ of ortho-phosphoric acid) was heated at $140^{\circ} \mathrm{C}$ on an oil bath for $1 \mathrm{hr}$. The solution was allowed to cool, poured with stirring onto ice-water and basified with ammonium hydroxide solution. The solid that formed was collected, washed with water and crystallized from the appropriate solvent to give $10(\mathrm{a}, \mathrm{b})$ and also $11(\mathrm{a}, \mathrm{b})$.

(B).

Compound $4 \mathrm{~d}$ or $4 \mathrm{e}$ was dissolved in $20 \mathrm{ml}$ of sulfuric acid (40\%) and wormed, then left to cool at room temperature for $24 \mathrm{hr}$. The solution was poured onto ice-water and basified with ammonium hydroxide solution. The solid that formed, was separated with filtration, washed and recrystallized from the appropriate solvent.

2-Acetyl-7-amino-3-methyl-5h-thiazolo[3,2-a]pyrimidin-5-one(10a)

Using compound $4 \mathrm{~d}$. The product was crystallized from dioxane in a $60 \%$ yield. $\mathrm{mp} 305^{\circ} \mathrm{C}$; IR spectrum $\left(\mathrm{KBr}, \mathrm{v}, \mathrm{cm}^{-1}\right)$ : $3250 \mathrm{~cm}^{-1}$ (broad) for $\mathrm{NH}_{2}$ group, $2900 \mathrm{~cm}^{-1}$ for $\mathrm{CH}, 1720 \mathrm{~cm}^{-1}$ and $1680 \mathrm{~cm}^{-1}$ for 2 (CO) groups. ${ }^{1} \mathrm{H}-\mathrm{NMR}(500$ $\left.\mathrm{MHz}, \mathrm{DMSO}-d_{6}\right) \delta \mathrm{ppm}$ : 2.08(s, $3 \mathrm{H}, \mathrm{CH}_{3}$, methyl of acetyl group), 03.04 (s, $3 \mathrm{H}, \mathrm{CH}_{3}$ methyl group), $6.00(\mathrm{~s}, 1 \mathrm{H}$, methine proton of the pyrimidine ring), 7.20 (br., s, $2 \mathrm{H}, \mathrm{NH}_{2}, \mathrm{D}_{2} \mathrm{O}$ exchangeable). Anal. calcd. for $\mathrm{C}_{9} \mathrm{H}_{9} \mathrm{~N}_{3} \mathrm{O}_{2} \mathrm{~S}(223.25)$; C, 48.42; H, 4.06; N, 18.82; S, 14.36\%. Anal. Found; C, 48.12; H, 4.36; N, 18.72; S, 14.45\%. MS (m/z): $223(48 \%)\left(\mathrm{M}^{+}\right)$.

\section{7-Amino-3-Phenyl-5h-Thiazolo[3,2-a]Pyrimidin -5-ONE (10b)}

Using compound $4 \mathrm{e}$. The product was crystallized from DMF in a $70 \%$ yield, mp $320^{\circ} \mathrm{C}$; IR spectrum $\left(\mathrm{KBr}, \mathrm{v}, \mathrm{cm}^{-1}\right): 3250 \mathrm{~cm}^{-1}$ (broad) for $\mathrm{NH}_{2}$ group, 2930 $\mathrm{cm}^{-1}$ for $\mathrm{CH}, 1695 \mathrm{~cm}^{-1}$ for (CO) group. ${ }^{1} \mathrm{H}-\mathrm{NMR}\left(500 \mathrm{MHz}\right.$, DMSO-d $\left.d_{6}\right) \delta \mathrm{ppm}$ : $5.08\left(\mathrm{~s}, 1 \mathrm{H}\right.$, methine proton of the pyrimidine ring), 6.50 (br., s, $2 \mathrm{H}, \mathrm{NH}_{2}, \mathrm{D}_{2} \mathrm{O}$ exchangeable), 7.37 (s, $1 \mathrm{H}, \mathrm{CH}$, thiazole proton), $7.40(\mathrm{~m} ., 5 \mathrm{H}$, aromatic protons). Anal.calcd.for $\mathrm{C}_{12} \mathrm{H}_{9} \mathrm{~N}_{3} \mathrm{OS}(243.28)$ : C, 59.24; $\mathrm{H}, 3.73 ; \mathrm{N}, 17.27 ; \mathrm{S}, 13.18 \%$. Anal. Found; C, 59.04; H, 3.53; N, 17.57; S, 12.88\%. MS (m/z): $243(41 \%)\left(\mathrm{M}^{+}\right)$.

$N$-(2-alkyl-7- amino-3- substituted-5h- thiazolo [3,2-a] pyrimidine-7-yl) acetamide $(11 a, b)$

Compound $4 \mathrm{~d}$ or $4 \mathrm{e}(10 \mathrm{mmole})$ was dissolved in a mixture of $10 \mathrm{ml}$ pyridine and $10 \mathrm{ml}$ acetic anhydride. The reaction mixture was heated under reflux for $5 \mathrm{hr}$, then poured onto ice-hydrochloric acid/water mixture. The deposited precipitate, thus formed, was filtered off, washed thoroughly with water then ethanol, dried and recrystallized from DMF, to furnish derivatives $11(\mathrm{a}, \mathrm{b})$. (11a)

N-(2-acetyl-3-methyl-5-oxo-5h-thiazolo[3,2-a] pyrimidine-7-yl) acet- amide 
Using compound $4 \mathrm{~d}$. The product was produced in a $(70 \%)$ yield. mp $330{ }^{\circ} \mathrm{C}$; IR spectrum $\left(\mathrm{KBr}, \mathrm{v}, \mathrm{cm}^{-1}\right): 3150 \mathrm{~cm}^{-1}$ for $\mathrm{NH}$ group, $2930 \mathrm{~cm}^{-1}$ for $\mathrm{CH}, 1720$ $\mathrm{cm}^{-1}, 1700 \mathrm{~cm}^{-1}$ and $1665 \mathrm{~cm}^{-1}$ for 3 (CO) groups ${ }^{1} \mathrm{H}-\mathrm{NMR}$ (500 MHz, DMSO$\left.d_{6}\right)$ Sppm: $1.99\left(\mathrm{~s}, 3 \mathrm{H}, \mathrm{CH}_{3}\right.$, methyl of acetyl group), $2.20\left(\mathrm{~s}, 3 \mathrm{H}, \mathrm{CH}_{3}\right.$, methyl of acetyl group), $3.00\left(\mathrm{~s}, 3 \mathrm{H}, \mathrm{CH}_{3}\right.$ methyl group attached to the thiazole ring), 6.90 ( $\mathrm{s}, 1 \mathrm{H}$, methane proton of the pyrimidine ring), 10.82 (br., s, $1 \mathrm{H}, \mathrm{NH}, \mathrm{D}_{2} \mathrm{O}$ exchangeable). Anal. calcd. for $\mathrm{C}_{11} \mathrm{H}_{11} \mathrm{~N}_{3} \mathrm{O}_{3} \mathrm{~S}(265.28) ; \mathrm{C}, 49.80 ; \mathrm{H}, 4.18 ; \mathrm{N}$, 15.84; S, 12.09\%. Anal. Found; C, 49.64; H, 3.93; N, 15.59; S, 12.29\%. MS $(\mathrm{m} / \mathrm{z}): 265(43.0 \%)\left(\mathrm{M}^{+}\right)$. (11b)

N-(2-acetyl-5-oxo-3-phenyl-5h-thiazolo[3,2-a] pyrimidine-7-yl)acet- amide

Using compound $4 \mathrm{e}$. The product was obtained in a $70 \%$ yield. $\mathrm{mp} 330^{\circ} \mathrm{C}$; IR spectrum $\left(\mathrm{KBr}, \mathrm{v}, \mathrm{cm}^{-1}\right): 3150 \mathrm{~cm}^{-1}$ for $\mathrm{NH}$ group, $2930 \mathrm{~cm}^{-1}$ for $\mathrm{CH}, 1700 \mathrm{~cm}^{-1}$ and $1665 \mathrm{~cm}^{-1}$ for $(2 \mathrm{CO})$ groups. ${ }^{1} \mathrm{H}-\mathrm{NMR}\left(500 \mathrm{MHz}, \mathrm{DMSO}-d_{6}\right) \delta \mathrm{ppm}: 2.10(\mathrm{~s}$, $3 \mathrm{H}, \mathrm{CH}_{3}$, methyl of acetyl group), $2.20\left(\mathrm{~s}, 3 \mathrm{H}, \mathrm{CH}_{3}\right.$, methyl of acetyl group), $6.50\left(\mathrm{~s}, 1 \mathrm{H}\right.$, methane proton of the pyrimidine ring), 10.50 (br., s, $1 \mathrm{H}, \mathrm{NH}, \mathrm{D}_{2} \mathrm{O}$ exchangeable). Anal. calcd. for $\mathrm{C}_{14} \mathrm{H}_{11} \mathrm{~N}_{3} \mathrm{O}_{2} \mathrm{~S}$ (285.28); C, 58.93; H, 3.89; N, 14.73; S, 11.24\%. Anal. Found; C, 59.09; H, 3.70; N, 14.43; S, 11.54\%. MS $(\mathrm{m} / \mathrm{z}): 285(32.0 \%)\left(\mathrm{M}^{+}\right)$.

General procedure for the preparation of 6-Amino-2-(3,5-Dimethyl-1-Aryl-1hPyrazol-4-Yl)Thio)Pyrimidine-4(3h) - One(12a,b)

A mixture of compound $4 \mathrm{e}(02.41 \mathrm{gm}, 10 \mathrm{mmole})$ and phenyl hydrazine (01.08gm, $10 \mathrm{mmole})$ or hydrazine hydrate $99 \%(00.50 \mathrm{gm}, 10 \mathrm{mmole})$ was heated under reflux in dry dioxane for $3 \mathrm{hr}$. The reaction mixture was poured onto acidified water. The separated solid was filtrated off, washed and recrystallized from dioxane to furnish $12(a, b)$.

6-amino-2-((3,5-dimethyl-1-phenyl-1h-pyrazol-4-yl)thio)pyrimidine-4(3h)-one (12a)

Using phenyl hydrazine. The product was obtained in an $87 \%$ yield. mp $220^{\circ} \mathrm{C}$; IR spectrum $\left(\mathrm{KBr}, \mathrm{v}, \mathrm{cm}^{-1}\right): 3500 \mathrm{~cm}^{-1}$ for $\mathrm{OH}$ group, $3400 \mathrm{~cm}^{-1}$ (Broad) for $\mathrm{NH}_{2}$ group, $3150 \mathrm{~cm}^{-1}$ for $\mathrm{NH}, 2920 \mathrm{~cm}^{-1} \mathrm{CH}, 1700 \mathrm{~cm}^{-1}$ for (CO) group. ${ }^{1} \mathrm{H}-\mathrm{NMR}\left(500 \mathrm{MHz}, \mathrm{DMSO}-d_{6}\right) \delta \mathrm{ppm}: 2.20$ (s, 3H, methyl group), 2.30 (s, 3H, methyl group), $5.00(\mathrm{~s}, 1 \mathrm{H}, \mathrm{CH}$, methine proton of the pyrimidine ring), 6.49 (br., $\mathrm{s}, 2 \mathrm{H}, \mathrm{NH}_{2}, \mathrm{D}_{2} \mathrm{O}$ exchangeable), 7.50 (m, 3H, aromatic protons), 7.55 (d., $2 \mathrm{H}$, $J=6.8 \mathrm{~Hz}$, aromatic protons), 11.55 (br., s, $1 \mathrm{H}, \mathrm{OH}$ group, $\mathrm{D}_{2} \mathrm{O}$ exchangeable). Anal. calcd. for $\mathrm{C}_{15} \mathrm{H}_{15} \mathrm{~N}_{5} \mathrm{OS}$ (313.38); C, 57.49; H, 4.82; N, 22.35; S, 10.23\%. Anal. Found; C, 57.19; H, 4.92; N, 22.05; S, 10.53\%. MS (m/z): $313(49 \%)\left(\mathrm{M}^{+}\right)$.

6-amino-2-((3,5-dimethyl-1h-pyrazol-4-yl)thio)pyrimidine-4(3h)-one (12b)

Using hydrazine hydrate. The product was obtained in a $80 \%$ yield. $\mathrm{mp}$ $200^{\circ} \mathrm{C}$; IR spectrum $\left(\mathrm{KBr}, \mathrm{v}, \mathrm{cm}^{-1}\right): 3500 \mathrm{~cm}^{-1}$ for $\mathrm{OH}$ group, $3300 \mathrm{~cm}^{-1}$ (broad) for $\mathrm{NH}_{2}$ group, $3150 \mathrm{~cm}^{-1}$ for $\mathrm{NH}, 2920 \mathrm{~cm}^{-1} \mathrm{CH}, 1720 \mathrm{~cm}^{-1}$ for (CO) group. ${ }^{1} \mathrm{H}-\mathrm{NMR}\left(500 \mathrm{MHz}, \mathrm{DMSO}-d_{6}\right.$ ) $\delta$ ppm: 2.30(s, 6H, two methyl groups), 5.00 (s, $1 \mathrm{H}, \mathrm{CH}$, methine proton of the pyrimidine ring), 6.49(br., s, $2 \mathrm{H}, \mathrm{NH}_{2}, \mathrm{D}_{2} \mathrm{O}$ Egypt. J. Chem. 59, No.5 (2016) 
exchangeable), 11.50 (br., s, 1H, OH group, D2O exchangeable). Anal. calcd. for $\mathrm{C}_{9} \mathrm{H}_{11} \mathrm{~N}_{5} \mathrm{OS}(237.28) ; \mathrm{C}, 45.56 ; \mathrm{H}, 4.67 ; \mathrm{N}, 29.51 ; \mathrm{S}, 13.51 \%$. Anal. Found; C, 45.77; H, 4.92; N, 29.25; S, 13.53\%. $\mathrm{MS}(\mathrm{m} / \mathrm{z}): 237(42 \%)\left(\mathrm{M}^{+}\right)$.

\section{6-amino-3,4-dihydro-2-hydrazinopyrlmidin-4-one(13)}

A solution of $(01.57 \mathrm{gm}, 10$ mmole $)$ of $4 \mathrm{a}$ in $50 \mathrm{ml}$ of ethanol was treated with an excess ( $1 \mathrm{ml}, 02.00 \mathrm{mmole})$ of hydrazine hydrate $99 \%$. The solution was heated under reflux till evolution of methane-thiol ceased. The hydrazino derivative which precipitated during reflux was collected and recrystallized from ethanol/water $(1: 1)$ to produce 13 in a $75 \%$ yield; m.p. $245{ }^{\circ} \mathrm{C}$, not depressed when admixed with an authentic sample. All spectral and elemental data were identical to those reported in literature ${ }^{(17)}$.

General procedure for the preparation of 2-arylamino-6-amino -3,4-dihydropyrlmldln-4-one(14a-b)

A mixture of $4 \mathrm{a}(1.57 \mathrm{gm}, 10 \mathrm{mmole})$ and either aniline $(0.93 \mathrm{gm}, 10 \mathrm{mmole})$ or p-chloroaniline $(01.28 \mathrm{gm}, 10 \mathrm{mmole})$ was heated at $140{ }^{\circ} \mathrm{C}$ till evolution of methane-thiol ceased. The residue was triturated with ethanol and the solid, so obtained, was filtered off, washed with ethanol, dried and recrystallized from the appropraite solvent to give $14(\mathrm{a}, \mathrm{b})$.

6-amino -3,4-dihydro-2-phenylamino-pyrlmldln-4-one (14a)

Using aniline. The product was crystallized from ethanol to produce $14 \mathrm{a}$ in a $60 \%$ yield. .mp $285^{\circ} \mathrm{C}$; IR spectrum $\left(\mathrm{KBr}, \mathrm{v}, \mathrm{cm}^{-1}\right): 3300 \mathrm{~cm}^{-1}$ for $\mathrm{NH}_{2}$ group , $3100 \mathrm{~cm}^{-1}$ (broad) for NH group, $1675 \mathrm{~cm}^{-1}$ for 2 (CO) groups.; ${ }^{1} \mathrm{H}-\mathrm{NMR}(500$ $\left.\mathrm{MHz}, \mathrm{DMSO}-d_{6}\right) \delta \mathrm{ppm}$ : $5.06(\mathrm{~s}, 1 \mathrm{H}, \mathrm{CH}$, methine proton of pyrimidine ring), 7.01 (br., s, $4 \mathrm{H}, \mathrm{NH}_{2}, 2 \mathrm{NH}, \mathrm{D}_{2} \mathrm{O}$ exchangeable), 7.50 (m, 5H, aromatic protons), 10.55 (br., s, $1 \mathrm{H}, \mathrm{OH}$ group, $\mathrm{D}_{2} \mathrm{O}$ exchangeable). Anal. calcd. for $\mathrm{C}_{10} \mathrm{H}_{10} \mathrm{~N}_{4} \mathrm{O}$ (202.21); C, 59.40; H, 4.98; N, 27.71\%. Anal. Found; C, 59.10; H, 5.18; N, $27.52 \%$. $\mathrm{MS}(\mathrm{m} / \mathrm{z}): 202(53 \%)\left(\mathrm{M}^{+}\right)$.

\section{6-amino-3,4-dihydro-2-(4-chlorophenylamino)-pyrlmldln-4-one (14b)}

Using p-chloroaniline. The product was crystallized from DMF to give $14 \mathrm{~b}$ in a $60 \%$ yield. mp $310^{\circ} \mathrm{C}$; IR spectrum $\left(\mathrm{KBr}, \mathrm{v}, \mathrm{cm}^{-1}\right): 3300 \mathrm{~cm}^{-1}$ for $\mathrm{NH}_{2}$ group, $3100 \mathrm{~cm}^{-1}-2870 \mathrm{~cm}^{-1}$ (Broad) for $\mathrm{CH}$ and $\mathrm{NH}$ with intramolecular hydrogen bond, $1675 \mathrm{~cm}^{-1}$ for 2 (CO) groups. ${ }^{1} \mathrm{H}-\mathrm{NMR}\left(500 \mathrm{MHz}, \mathrm{DMSO}-\mathrm{d}_{6}\right) \delta \mathrm{ppm}: 5.00(\mathrm{~s}$, $1 \mathrm{H}, \mathrm{CH}$, methine proton of pyrimidine ring), 7.00 (br., s, $4 \mathrm{H}, \mathrm{NH}_{2}, 2 \mathrm{NH}, \mathrm{D}_{2} \mathrm{O}$ exchangeable), $7.20-7.40$ (dd, $2 \mathrm{H}, J=8.5 \mathrm{~Hz}, 2 \mathrm{H}, \mathrm{AB}$ system aromatic protons), 7.50-7.60(dd, $2 \mathrm{H}, J=8.5 \mathrm{~Hz}, 2 \mathrm{H}, \mathrm{AB}$ system aromatic protons), 10.50 (br., s, $1 \mathrm{H}$, $\mathrm{OH}$ group, $\mathrm{D}_{2} \mathrm{O}$ exchangeable). Anal. calcd. for $\mathrm{C}_{10} \mathrm{H}_{9} \mathrm{ClN}_{4} \mathrm{O}(236.66) ; \mathrm{C}, 50.75$; H, 3.83; Cl, 14.98; N, 23.67\%. Anal. Found; C, 50.55; H, 3.60; Cl, 15.09; N, $23.37 \%$. MS(m/z): $236(25 \%)\left(\mathrm{M}^{+}\right), 238(22 \%)$. 


\section{Conclusion}

As evidenced from all the above arguments, 6-amino-2-thiouracil (1) has a wide range of applications which encourage us to use it for developing new synthetic routes with the possibility to obtain end products which could be used in many applications.

\section{References}

1. Crepaldi, P., Cacciari, B., Bonache, M.C., Spalluto, G., Kuegelgen, I.V., Hoffmann, K., Pugliano, M., Razzari, C., Cattaneo, M., Varani, K., and Borea, P.A., J. Bioorg and Med Chem , 17 (13), 4612 - 4621 (2009).

2. Mohamed, N.R., El-Saidi, M.M., Ali, Y.M. and Elnagdi, M.H., J. Bioorg and Medicinal Chem , 15, (18), 6227-6235 (2007).

3. Mohamed, M.S., Awad, S.M. and Amira, S.I., Molecules, 15 (3),1882-1890 (2010).

4. Hoever, G., Baltina, L., Michaelis, M., Kondratenko, R., Baltina, L., Tolstikov, G.A., Doerr, H.W. and Cinatl, J., J. of Med Chem 48 (4), 1256-1259 (2005).

5. Sara, C., Andrea, S., Angelo, R., Olga, B., Nicoletta, A., Maria, B., Franco, D., Massimiliano, T., Thomas, G. and Elisabetta, B., J. Bioorg and Med Chem. 17 (10), 3580-3587 (2009).

6. Tolstikov, G.A., Myshkin, V.A., Baltina, L.A.,Murinov, Yu.I. and Srubilin, D.V., et al., Pharma Chem. J. 30 (5), 36- 38 (1996).

7. Katori, E., Nagano, T., Kunieda, T. and Hirobe, M., Chem \& Pharma Bull. 29 (10), 3075-3077 (1981)

8. Eastman Kodak Co., Patent; US2819965 (1956).

9. Talukdar, P.B., Sengupta, S.K. and Datta, A.K., Indian J. Chem.Section B: Org Chem Including Med. Chem. 25, 275-278 (1986).

10. Sayle, K.L., Bentley, J., Boyle, F.T., Calvert, A.H., Cheng, Y., Curtin, N.J., Endicott, J.A., Golding, B.T., Hardcastle, I.R., Jewsbury, P. and Mesguiche, V., et al., J. Bioorg \& Med Chem Letters, 13 (18), 3079-3082 (2003).

11. Wyrzkiewicz, E., Wybieralska, J. and Apuchn, A.I., Polish J. Chem. 61 (1-3), 253-257 (1987).

12. Augustin, LA., Fantini, J., Mootoo, D.R., Augustin, L.A. and Fantini, J., $J$. Bioorg and Med Chem., 14, 1182-1188 (2006).

13. Justin, T., Fischedic, R.G., Arno, H. and Rob, V., J. Photochem analysis , 20, 421426 (2009).

14. Nagy, P., Gorbe, I., Pany, V. and Fcdor, L., Rom J., 63, 828 (1978).

Egypt. J. Chem. 59, No.5 (2016) 
15. Aly, A.S., Abu-Zied, Kh.M. and Gaafar, A.M., Egypt. J. Chem. 53, 541-552 (2010).

16. Brown, D.J. and Nagamatsu, T., Australian Journal of Chemistry, 32 (7), 1585 (1979).

17. Hafez, Hend N. and El-Gazzar, Abdel-Rahman B.A., Bioorganic and Medicinal Chemistry Letters, 19 (15), 4143-4147 (2009).

تثييد كيميائى لمشتقات 6-امينو-2-ثيويور اسيل وجليكوسيدتها

علاء الاين مصطفى جعفر'، أحمد صالح على'، خديجة محم أبوزيد'، اسماء عماد

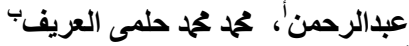

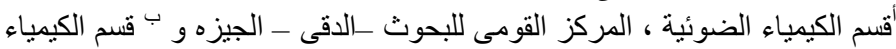

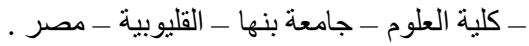

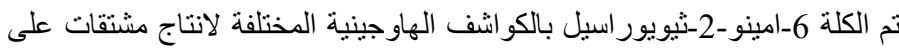

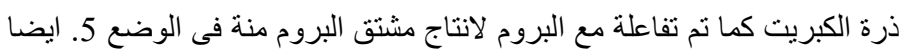

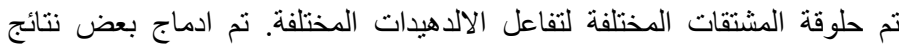

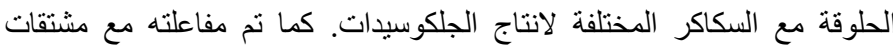

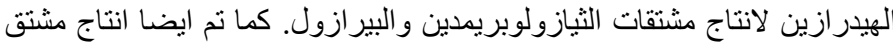

الهيدرازين عند مفاعلة احدى مشتقان الاكلكة مع الهيدرازين هيدرات.

تم التاكد من التراكيب الناتجة بو اسطة التحاليل الدقيقة والتحاليل الطيفية المختلفة. 